\title{
Assessing the impact of heat treatment on antimicrobial resistance genes and their potential uptake by other 'live' bacteria
}

\section{FSA Project: FS307036}

\section{Submission Date: July 2021}

\section{Christian James ${ }^{1}$, Ronald A. Dixon ${ }^{2}$, Luke Talbot ${ }^{1}$,}

\section{Stephen J. James ${ }^{1}$, Nicola Williams ${ }^{3}$, Bukola A. Onarinde ${ }^{4}$}

${ }^{1}$ Food Refrigeration \& Process Engineering Research Centre (FRPERC), TEC Partnership, Grimsby Institute, Nuns Corner, Grimsby, North East Lincolnshire, DN34 5BQ

2 School of Life Sciences, University of Lincoln, Joseph Banks Laboratories, Green Lane, Lincoln, LN6 7DL

${ }^{3}$ Institute of Infection, Veterinary and Ecological Sciences, University of Liverpool, Leahurst Campus, Neston, CH64 7TE

${ }^{4}$ National Centre for Food Manufacturing (NCFM), University of Lincoln, Park Road, Holbeach, Spalding, Lincolnshire, PE12 7PT
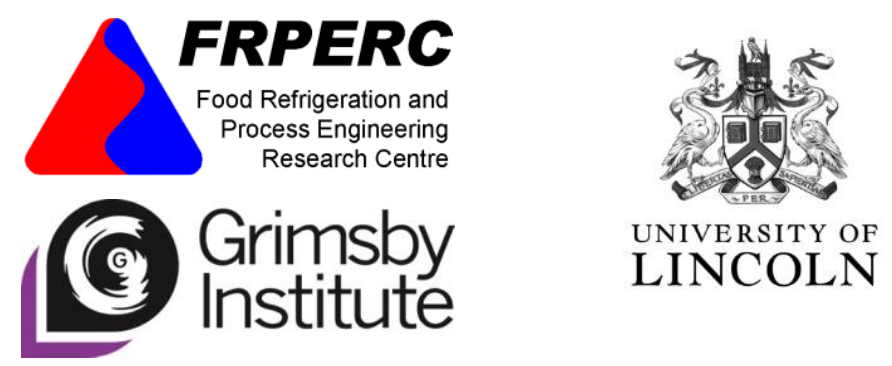

This work was funded by the Food Standards Agency (FSA)

https://doi.org/10.46756/sci.fsa.oxk434 


\section{(c) Crown Copyright 2021}

This report has been produced by the TEC Partnership (Grimsby Institute), University of Lincoln, and University of Liverpool under a contract placed by the Food Standards Agency (the FSA). The views expressed herein are not necessarily those of the FSA. The TEC Partnership, the University of Lincoln, and University of Liverpool warrants that the work associated with this contract has been carried out in accordance with the highest academic standards and reasonable endeavours have been made to achieve the degree of reliability and accuracy appropriate to work of this kind.

However, the TEC Partnership (Grimsby Institute), the University of Lincoln, and University of Liverpool do not have control over the use to which the results of this work may be put by the funder and the funder will therefore be deemed to have satisfied itself in every respect as to the suitability and fitness of the work for any particular purpose or application.

In no circumstances will the TEC Partnership, the University of Lincoln, and University of Liverpool, its servants or agents accept liability however caused arising from any error or inaccuracy in any operation, advice or report arising from this work, nor from any resulting damage, loss, expenses, or claim. 


\section{Contents}

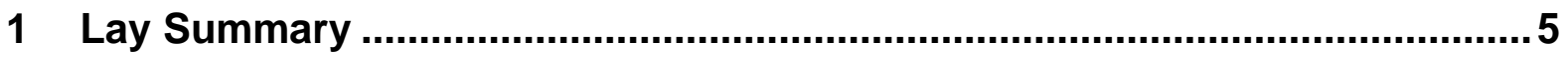

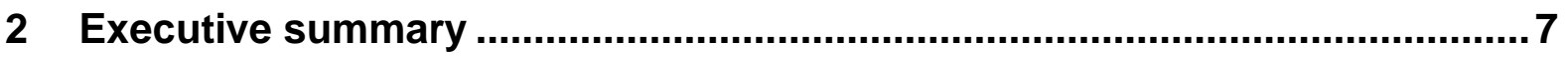

3 Glossary and abbreviations .................................................................... 11

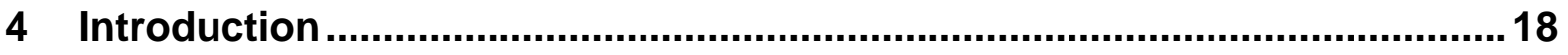

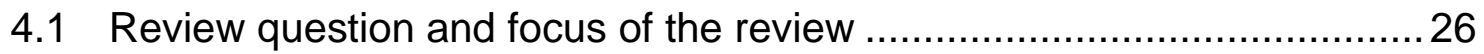

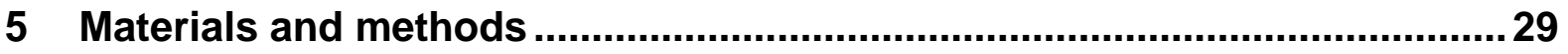

5.1 Flowchart of knowledge synthesis .................................................. 33

6 Review of published literature on the impact of heat treatment of food on

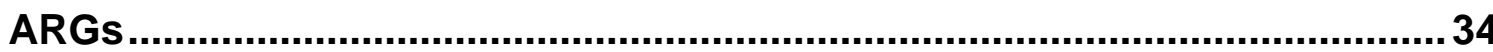

6.1 Are AMR bacteria more heat-resistant than non-AMR bacteria?.............36

6.2 Is there evidence that ARGs can transfer from heat-treated AMR bacteria to other bacteria? ............................................................................ 50

6.3 Is there compelling evidence to show that heat completely destroys DNA (particularly ARGs either as non-cellular DNA or within AMR bacteria)? 60

6.4 Can ARGs be up taken by surrounding viable bacteria present in other settings, including the human gut?

6.5 What is the impact of different heat treatments on ARG uptake by viable bacteria?

6.6 Is there any evidence of uptake of heat damaged DNA, and particularly ARGs, by pathogenic and non-pathogenic bacteria?

6.7 Is there any evidence to suggest that the behaviour of chromosomal DNA and plasmid DNA in response to heat differs?

6.8 Is there any evidence to suggest that ARGs can transfer via heat-tolerant phages/GTAs? 
6.9 Is there any evidence on the role of membrane vesicles (MVs) in the survival and transfer of ARGs from AMR bacteria subjected to heat treatments?

7 Conclusions and recommendations for further work................................66

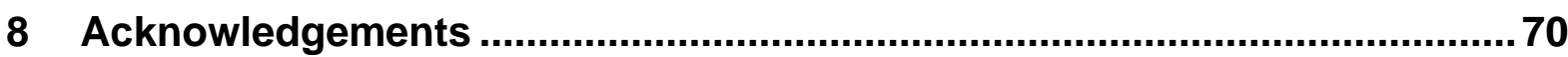

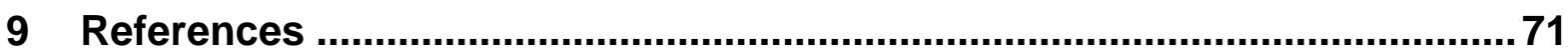




\section{Lay Summary}

Food plays an important role in the development and spread of antimicrobial resistance (AMR) and is one of many routes by which consumers can be exposed to AMR bacteria. The ingestion of pathogenic AMR bacteria via food may result in human illness which may be difficult to treat with antibiotics. Non-pathogenic AMR bacteria also contribute to the reservoir of AMR within our food chain which may lead to the onward transmission of antimicrobial resistance genes (ARGs) to pathogenic bacteria. The Food Standards Agency (FSA) advises that thorough cooking combined with good hygiene when handling raw meats and foods will help to mitigate consumers' risk of exposure to AMR bacteria and ARGs in food. Whilst thoroughly cooking will 'kill' AMR bacteria, it is unclear whether this will inactivate their ARGs and prevent resistance genes being passed onto other 'live' bacteria. The overall aim of this project was to carry out a broad critical review of the available scientific literature on the impact of heat treatment on ARGs that may be present in heat-killed foodborne bacteria and their potential uptake by surrounding viable bacterial communities, including in the human gut and foods.

Two scientific literature databases (Web of Science, and PubMed) were searched for relevant publications, supplemented by focused Google searches, searching within relevant publications, and through contact with authors. Literature relating to AMR and heat treatments was rare, and while 17 publications were found that had evidence on the heat resistance of AMR bacteria, only four publications were found that had specifically studied the impact of heat treatments on ARGs. Due to the small number of publications identified and different laboratory methodologies used in these studies no statistical analysis was possible, a narrative approach was taken to their review and to the review of supplementary materials.

The literature review showed that there is evidence that AMR bacteria are likely to be no more heat-resistant than non-AMR bacteria and that there is therefore evidence that heat treatments sufficient to kill non-AMR bacteria (such as $70^{\circ} \mathrm{C}$ for at least 2 min, or the equivalent) will be equally effective in killing AMR bacteria. The 
evidence as to whether viable ARGs may persist after such heat treatments is sparse, and also whether these genes can be transferred to other bacteria.

Whilst the published evidence is limited, the studies identified do provide some evidence that ARGs may persist in cooked foods following heat treatments that are effective in killing AMR bacteria. If ARGs are not sufficiently damaged during heat treatment, it is possible that genes could be subsequently taken up by other bacteria. Although the occurrence of this transfer is probably rare. None of the published studies demonstrated whether the ARGs from heat-treated AMR bacteria could be 'taken up' by other 'live' bacteria in the human gut. There is currently not enough evidence to determine if there is a risk to human health and we would recommend that further focused practical research is undertaken to produce clear evidence that can be used to fully assess whether there is a risk of exposure to ARGs in heattreated/cooked food. 


\section{Executive summary}

Antimicrobial resistance (AMR) is a complex issue driven by a variety of interconnected factors enabling microorganisms to withstand the killing or microstatic effects of antimicrobial treatments, such as antibiotics, antifungals, disinfectants, preservatives. Microorganisms may be inherently resistant to such treatments or can change and adapt to overcome the effects of such treatments. Microorganisms can acquire antimicrobial resistance genes (ARGs) because of mutation or from other microorganisms through a range of mechanisms. The widespread use of antimicrobial treatments is known to result in selection for AMR in microorganisms. AMR and ARGs are a major public health issue worldwide and it is estimated that unless action is taken now to tackle AMR the global impact of AMR could be 10 million deaths annually by 2050 and cost up to US $\$ 100$ trillion in cumulative lost economic output (O'Neill Report, 2014).

It is recognised that anthropogenic, commensal, and environmental microorganisms all contribute to the reservoir of ARGs, collectively forming the antimicrobial resistome (Wright, 2007). Relatively little is known regarding the role of heattreated/cooked food in disseminating AMR, and whether heating/cooking is sufficient to inactivate ARGs to the extent that resistance is not passed onto other 'live' bacteria.

This study was undertaken to critically review the available scientific literature for assessing the impact of heat treatment of food on ARGs, and the potential uptake of such ARGs by surrounding viable bacterial communities resident in other foods and the human gut.

For the purpose of this review, heat treatments were regarded as any thermal processes that are undertaken during the processing or prior to consumption of any foods. The review focused particularly, but not exclusively, on what scientific evidence exists that provides an understanding on whether cooking (heating) food to eliminate bacterial contamination can also induce sufficient damage to ARGs to 
prevent their uptake by surrounding viable bacteria present in other settings, including other foods and the human gut.

The review question was defined as:

"Do different heat treatments applied to eliminate bacterial contamination in foods also induce sufficient damage to ARGs to prevent or inhibit their uptake by surrounding viable bacteria present in other settings, including the human gut and other foods?"

Systemic searching of two literature databases (Web of Science, and PubMed) was undertaken, supplemented by additional records identified through other sources. A total of 2681 of publications were identified between 1990 and May 2021, which were reduced to 247 after screening the titles and abstracts. This total was further reduced to 53 , from which some data were extracted after appraising the full publications. This clearly indicated that literature relating to AMR bacteria and ARGs and heat treatments was sparse.

Of these 53 publications identified that were considered eligible for some data extraction, only four were found that had studied the impact of heat treatments on ARGs. The majority of publications identified related to the relative heat resistance of various AMR bacteria in comparison to non-AMR strains and serotypes /serovars.

Nine publications were reviews with some mention of the impact of heat on AMR bacteria, while 17 had evidence on the relative heat resistance of AMR bacteria in comparison to non-AMR bacteria. These publications provide evidence that AMR bacteria are likely to be no more heat-resistant than non-AMR bacteria. There is therefore evidence that heat treatments sufficient to kill non-AMR bacteria (such as $70^{\circ} \mathrm{C}$ for at least $2 \mathrm{~min}$, or the equivalent) will be equally effective in killing AMR bacteria. 
Most of these publications have not considered whether ARGs may persist after such heat treatments, and whether these genes could be transferred to other bacteria.

Only four publications were identified that provide some evidence on the fate of ARGs after heat treatments. Due to the small number of publications identified and different laboratory methodologies used in the studies no statistical analysis was possible. Three of the four studies provided evidence that ARGs can at least be identified after heat treatments that are effective at inactivating AMR bacteria, but there is no certainty that such ARGs are intact and functional.

Of the four studies identified, one (Koncan et al., 2007) used in vitro experiments to mimic cooking processes. Another in vitro study (Taher et al., 2020a) mimicked commercial milk pasteurisation, whilst the third (Le Devendec et al., 2018) was not designed to mimic any particular heat treatment but did use strains originating from animal sources and temperatures and times similar to thermal processes used to treat and cook food. A further study on autoclaving (Masters et al., 1998) was considered relevant, but was not applied to food.

The in vitro mimic of cooking processes study (Koncan et al., 2007) detected the presence of ARGs after cooking but did not demonstrate that these genes were transferable to other bacteria. The other three studies did demonstrate that plasmidencoded ARGs could be transferred to other bacteria following heat treatments under laboratory conditions.

The ARG considered by Koncan et al. (2007) was aac(6')-le-aph(2")-la, while Taher et al. (2020a) considered blaZ, mecC, tetK, and Le Devendec et al. (2018) considered blacтх-M-1, blacmy-2, tetA, strA. Masters et al. (1998) did not give any details of the gene considered. 
These studies did not establish how likely was the occurrence of such transfer in the field. One of the studies (Le Devendec et al., 2018) theorised that natural transfer is probably rare.

None of the studies demonstrated whether ARGs from heat-treated AMR bacteria could be taken up by other live bacteria in the human gut after ingestion.

In conclusion, only a small number of studies were identified on the persistence of ARGs in heat-treated foods and their possible uptake by surrounding viable bacteria present in other settings, such as the human gut and other foods. Because of differences in conditions, these studies were not directly comparable.

While the literature suggests that adequate heat treatment / cooking (e.g., cooking until the middle of the food commodity reaches $70^{\circ} \mathrm{C}$ for at least $2 \mathrm{~min}$, or the equivalent) should be effective in 'killing' AMR bacteria in food, there is very little evidence if intact and functional ARGs are released from AMR bacteria following such heat treatments. Similarly, there does not appear to be any convincing data for the ready transfer of $A R G$ s to the commensal bacteria of the mammalian gastrointestinal tract following cooking.

Evidence to determine if there is a risk of transfer is sparse. We would therefore recommend further focused practical research be undertaken to provide evidence for a full assessment of risk in relation to transfer of ARGs from heat-treated foods to bacteria in other matrices. 


\section{Glossary and abbreviations}

\begin{tabular}{|c|c|}
\hline Term/Abbreviation & Definition/Description \\
\hline Amplification & $\begin{array}{l}\text { In the context of this report, amplification tests produce } \\
\text { many copies from a target sequence of DNA (amplification). } \\
\text { This enables the detection of specific fragments of DNA, for } \\
\text { example, ARGs, by incorporating fluorescent labels during } \\
\text { amplification or subsequent electrophoresis. }\end{array}$ \\
\hline Antibiotic & $\begin{array}{l}\text { Antibiotics are a type of antimicrobial. An antibiotic is a drug } \\
\text { used to treat bacterial infections in both humans and } \\
\text { animals. They have no effect on viral or fungal infections. } \\
\text { Examples of antibiotics include penicillin, tetracyclines, } \\
\text { methicillin, and colistin. }\end{array}$ \\
\hline Antimicrobial & $\begin{array}{l}\text { Any substance that kills or stops the growth of } \\
\text { microorganism, such as antibiotics, antifungals, } \\
\text { disinfectants, and preservatives. }\end{array}$ \\
\hline AMR & $\begin{array}{l}\text { Antimicrobial resistance. } \\
\text { For the interpretation of AMR in this study, the WHO } \\
\text { definition was applied (WHO, 2018a): "Antimicrobial } \\
\text { resistance is resistance of a microorganism to an } \\
\text { antimicrobial drug that was originally effective for treatment } \\
\text { of infections caused by it. Resistant microorganisms } \\
\text { (including bacteria, fungi, viruses and parasites) are able to } \\
\text { withstand attack by antimicrobial drugs, such as antibacterial } \\
\text { drugs (e.g., antibiotics), antifungals, antivirals, and } \\
\text { antimalarials, so that standard treatments become } \\
\text { ineffective and infections persist, increasing the risk of } \\
\text { spread to others." }\end{array}$ \\
\hline ARG(s) & $\begin{array}{l}\text { Antimicrobial resistance gene. } \\
\text { An ARG is a gene implicated in or associated with conferring } \\
\text { resistance to one or more antimicrobial. The resistance may }\end{array}$ \\
\hline
\end{tabular}




\begin{tabular}{|c|c|}
\hline Term/Abbreviation & Definition/Description \\
\hline & $\begin{array}{l}\text { result from the presence or absence of a gene or specific } \\
\text { mutations acquired spontaneously or through evolution over } \\
\text { time. ARGs confer resistance, however clinical treatment } \\
\text { with higher doses of the microbial may still be effective. }\end{array}$ \\
\hline Bacteriophage & $\begin{array}{l}\text { Often shorted to phage, a bacteriophage is a virus that } \\
\text { parasitises a bacterium by infecting it and reproducing inside } \\
\text { it. Phages are capable of packaging part of their host's } \\
\text { genetic material (including ARGs) either by reproducing } \\
\text { within the host cell before lysing the cell (lytic) or through } \\
\text { incorporation into the host cell genome (lysogenic). Phages } \\
\text { cannot infect human cells. }\end{array}$ \\
\hline Conjugation & $\begin{array}{l}\text { A mechanism of HGT. A process requiring cell-to-cell } \\
\text { contact via cell surface pili or adhesins, through which DNA } \\
\text { is transferred from the donor cell to the recipient cell. }\end{array}$ \\
\hline $\mathrm{CCP}(\mathrm{s})$ & $\begin{array}{l}\text { Critical Control Point(s). } \\
\text { A CCP is a step in food handling where controls can be } \\
\text { applied to prevent or reduce any food safety hazard. }\end{array}$ \\
\hline $\mathrm{CFU}(\mathrm{s})$ & $\begin{array}{l}\text { Colony Forming Unit(s). } \\
\text { A unit used to estimate the number of viable, cells capable } \\
\text { of growing on the growth media used, microbial cells in a } \\
\text { sample. Colonies may arise from one cell or a group of } \\
\text { cells. May be expressed as log } 10 \text { per gram (g) or milli-litre } \\
(\mathrm{ml}) \text { of sample. }\end{array}$ \\
\hline ClAs & $\begin{array}{l}\text { Critically Important Antimicrobials. } \\
\text { There are some differences in the categorisation of CIAs } \\
\text { between different organisations. The WHO (WHO, 2018b) } \\
\text { categorises CIAs as meeting two criteria: }\end{array}$ \\
\hline
\end{tabular}




\begin{tabular}{|l|l|}
\hline Term/Abbreviation & Definition/Description \\
\hline $\begin{array}{l}\text { Criterion 1 (C1): The antimicrobial class is the sole, or one of } \\
\text { limited available therapies, to treat serious bacterial } \\
\text { infections in people. } \\
\text { Criterion 2 (C2): The antimicrobial class is used to treat } \\
\text { infections in people caused by either: (1) bacteria that may } \\
\text { be transmitted to humans from non-human sources, or (2) } \\
\text { bacteria that may acquire resistance genes from non-human } \\
\text { sources. }\end{array}$ \\
\hline Commensal & $\begin{array}{l}\text { An organism that uses food supplied in the internal or } \\
\text { external environment of the host without establishing a close } \\
\text { association with the host, for instance by feeding on its } \\
\text { tissues. }\end{array}$ \\
\hline Dielectric heating & $\begin{array}{l}\text { A form of heating in which an electrically insulating material } \\
\text { is heated by being subjected to an alternating } \\
\text { electromagnetic field, such as in a microwave oven. }\end{array}$ \\
\hline DSC & $\begin{array}{l}\text { Deoxyribonucleic acid. } \\
\text { Deoxyribonucleic acid is a molecule composed of two } \\
\text { polynucleotide chains that coil around each other to form a } \\
\text { double helix carrying genetic instructions for the } \\
\text { development, functioning, growth and reproduction of all } \\
\text { known organisms and many viruses. }\end{array}$ \\
\hline $\begin{array}{l}\text { Differential Scanning Calorimetry. } \\
\text { DSC is a thermo-analytical technique in which the difference } \\
\text { in the amount of heat required to increase the temperature } \\
\text { of a sample and reference is measured as a function of } \\
\text { temperature. DSC can be used to measure a number of } \\
\text { characteristic properties of a sample. }\end{array}$ \\
\hline
\end{tabular}




\begin{tabular}{|l|l|}
\hline Term/Abbreviation & Definition/Description \\
\hline D-value & $\begin{array}{l}\text { The time required to inactivate or reduce } 90 \% \text { of the initial } \\
\text { population of the microorganism, for instance, from } 10^{7} \text { to } \\
10^{6} \text { at a given temperature. }\end{array}$ \\
\hline EFSA & $\begin{array}{l}\text { European Food Safety Authority. } \\
\text { cells by inducing temporary pores in the cell membrane. }\end{array}$ \\
\hline Electroporation & $\begin{array}{l}\text { An acronym comprising the scientific names of six highly } \\
\text { virulent and AMR pathogens including: Enterococcus } \\
\text { faecium, Staphylococcus aureus, Klebsiella pneumoniae, } \\
\text { Acinetobacter baumannii, Pseudomonas aeruginosa, and } \\
\text { Enterobacter spp. }\end{array}$ \\
\hline ESKAPE & $\begin{array}{l}\text { Extended spectrum beta-lactamase. } \\
\text { ESBLs are enzymes produced by bacteria such as } \\
\text { Escherichia coli and Klebsiella. ESBLs mediate resistance } \\
\text { to cephalosporins. }\end{array}$ \\
\hline HGT & $\begin{array}{l}\text { UK Food Standards Agency. } \\
\text { Green Fluorescent Protein. } \\
\text { The GFP from the jellyfish (Aequorea Victoria) enables gene } \\
\text { expression in individual cells to be examined non- } \\
\text { destructively and in real time by using fluorescence } \\
\text { microscopy or flow cytometry. }\end{array}$ \\
\hline FSA & $\begin{array}{l}\text { Gene Transfer Agents. } \\
\text { GTAs are host-cell produced particles that resemble } \\
\text { transferring part of their host's genetic material (including } \\
\text { ARGs) to other cells. } \\
\text { Horizontal Gene Transfer }\end{array}$ \\
\hline GFP &
\end{tabular}




\begin{tabular}{|c|c|}
\hline Term/Abbreviation & Definition/Description \\
\hline & $\begin{array}{l}\text { Transfer of genetic material (including ARGs), among } \\
\text { different bacteria and species, other than by the } \\
\text { transmission of DNA from parent to daughter cell. There are } \\
\text { a number of mechanisms through which HGT can occur. }\end{array}$ \\
\hline Integron & $\begin{array}{l}\text { A type of MGE with the ability to capture and disseminate } \\
\text { genes (including ARGs). These genes are located on gene } \\
\text { cassettes (a term that is changing to integron cassette). } \\
\text { Though an integron does not necessarily include any gene } \\
\text { cassettes. Integrons can be found in plasmids, } \\
\text { chromosomes, and transposons. }\end{array}$ \\
\hline Lysis & $\begin{array}{l}\text { The breaking down of the membrane of a cell compromising } \\
\text { its integrity and the release of its contents. }\end{array}$ \\
\hline MDR & $\begin{array}{l}\text { Multi-Drug Resistance. } \\
\text { Resistance to three or classes of antimicrobial. }\end{array}$ \\
\hline MIC & $\begin{array}{l}\text { Minimum Inhibitory Concentration. } \\
\text { The lowest concentration of an antimicrobial that prevents } \\
\text { visible growth of a bacteria. }\end{array}$ \\
\hline $\begin{array}{l}\text { Microorganisms } \\
\text { (microbes) }\end{array}$ & $\begin{array}{l}\text { Organisms that include bacteria, viruses, fungi, and } \\
\text { parasites. }\end{array}$ \\
\hline MGE(s) & $\begin{array}{l}\text { Mobile Genetic Element. } \\
\text { MGEs, also known as transposable elements (Tes), are } \\
\text { fragments/sequences of DNA that can move around. They } \\
\text { can encode a variety of virulence or resistance determinants } \\
\text { (such as ARGs) that can change places on a chromosome, } \\
\text { and can be transferred between chromosomes, between } \\
\text { bacteria, or even between species. Types of MGEs include } \\
\text { plasmids, integron gene cassettes, and transposable } \\
\text { elements. }\end{array}$ \\
\hline
\end{tabular}




\begin{tabular}{|l|l|}
\hline Term/Abbreviation & Definition/Description \\
\hline MRSA & $\begin{array}{l}\text { Methicillin-Resistant Staphylococcus aureus. } \\
\text { MVs are proteo-liposomal nanoparticles produced by both } \\
\text { Gram-negative and Gram-positive bacteria generally in } \\
\text { response to environmental stresses. They have diverse } \\
\text { functions, including the transport of virulence factors, DNA } \\
\text { transfer (including ARGs), interception of bacteriophages, } \\
\text { antibiotics and eukaryotic host defence factors, cell } \\
\text { detoxification and bacterial communication. }\end{array}$ \\
\hline NAP & $\begin{array}{l}\text { National Action Plan } \\
\text { UK Government 5-year (2019 to 2024) AMR National Action } \\
\text { Plan (NAP) to tackling antimicrobial resistance. }\end{array}$ \\
\hline Plasmid & $\begin{array}{l}\text { A type of MGE in a cell that can replicate independently of } \\
\text { the chromosomes, typically a small circular DNA strand in } \\
\text { the cytoplasm of a bacterium. Plasmids can carry and } \\
\text { transfer ARGs from the host to other cells, via other MGEs } \\
\text { (integron gene cassettes and transposable elements). }\end{array}$ \\
\hline Radio frequency & $\begin{array}{l}\text { Polymerase Chain Reaction. } \\
\text { A technique used to "amplify" small segments of DNA by } \\
\text { cycling targeted by complementary sequences of primers } \\
\text { (oligonucleotides). }\end{array}$ \\
\hline PCR & $\begin{array}{l}\text { Quantitative Polymerase Chain Reaction. } \\
\text { The main difference between PCR and qPCR is that PCR is } \\
\text { a qualitative technique whereas qPCR is a quantitative } \\
\text { technique. }\end{array}$ \\
\hline frequency.
\end{tabular}




\begin{tabular}{|c|c|}
\hline Term/Abbreviation & Definition/Description \\
\hline RTE & $\begin{array}{l}\text { Ready-to-eat. } \\
\text { Used to describe foods that are ready for consumption } \\
\text { without prior preparation or cooking. }\end{array}$ \\
\hline Spp. & Species. \\
\hline STEC & Shiga Toxin-producing Escherichia coli. \\
\hline Transduction & $\begin{array}{l}\text { A mechanism of HGT. This is a bacteriophage (and related } \\
\text { particles, such as GTAs) mediated transfer process. The } \\
\text { transfer of short fragments of DNA (such as ARGs) from one } \\
\text { cell into another via a bacteriophage (or related particle). }\end{array}$ \\
\hline Transformation & $\begin{array}{l}\text { A mechanism of HGT. The uptake of short fragments of } \\
\text { naked DNA (such as ARGs) by naturally transformable } \\
\text { bacteria. }\end{array}$ \\
\hline Transposon & $\begin{array}{l}\text { A type of MGE. A chromosomal segment that can undergo } \\
\text { transposition, especially a segment of bacterial DNA that } \\
\text { can be transferred as a whole between chromosomal, } \\
\text { phage, and plasmid DNA in the absence of a } \\
\text { complementary sequence in the host DNA. }\end{array}$ \\
\hline VBNC & $\begin{array}{l}\text { Viable But Non-Culturable. } \\
\text { VBNC cells are defined as live bacteria that do not either } \\
\text { grow or divide but remain metabolically active. Such bacteria } \\
\text { cannot be cultivated on conventional media (they do not } \\
\text { form colonies on solid media, they do not change broth } \\
\text { appearance), but their existence can be proved using other } \\
\text { methods. }\end{array}$ \\
\hline WHO & World Health Organisation (of the United Nations). \\
\hline
\end{tabular}




\section{Introduction}

The World Health Organization (WHO) definition of AMR is "resistance of a microorganism to an antimicrobial drug that was originally effective for treatment of infections caused by it. Resistant microorganisms (including bacteria, fungi, viruses and parasites) are able to withstand attack by antimicrobial drugs, such as antibacterial drugs (e.g., antibiotics), antifungals, antivirals, and antimalarials, so that standard treatments become ineffective and infections persist, increasing the risk of spread to others" (WHO, 2018a).

AMR microorganisms and $A R G$ s are a major public health issue worldwide. It is estimated that unless action is taken now to tackle AMR the global impact of AMR could be 10 million deaths annually by 2050 and cost up to US $\$ 100$ trillion in cumulative lost economic output (O'Neill Report, 2014).

Addressing the public health threat posed by AMR is a national strategic priority for

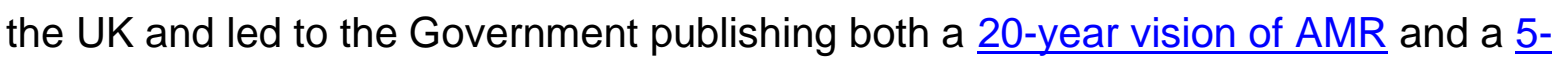
year (2019 to 2024) AMR National Action Plan (NAP) which sets out actions to slow the development and spread of AMR with a focus on antimicrobials. The NAP used an integrated 'One-Health' approach which spanned people, animals, agriculture, and the environment and calls for activities to "identify and assess the sources, pathways, and exposure risks" of AMR. The FSA have and are continuing to contribute to delivery of the NAP through furthering our understanding of the role of the food chain and AMR, conserving the effectiveness of current treatments through the adoption of good hygiene practices, and encouraging the food industry to reduce usage of antimicrobials where possible. ARGs that result in resistance to critically important antimicrobials are of particular concern to the FSA.

It is recognised that anthropogenic, commensal, and environmental microorganisms all contribute to the reservoir of ARGs collectively forming the antimicrobial resistome (Wright, 2007). AMR may be intrinsic or acquired. Intrinsic microorganisms are inherently resistant to certain antimicrobials (Verraes et al., 
2013). AMR can also be acquired either because of mutation (e.g., genomic point mutations) or the acquisition of resistance genes by horizontal gene transfer (Verraes et al., 2013; Munita \& Arias, 2016). Microorganisms may be resistant to just one antimicrobial or to many (multi-resistant or multi-drug resistant; MDR), with cross resistance depending on which ARGs and other mechanisms of resistance are present (such as, enzymatic, permeability barriers, and efflux pumps). This can make infections caused by these organisms difficult to treat and cause illness to persist, with recognised extra costs and increased morbidity and mortality (Likotrafiti et al., 2018).

The transmission of AMR microorganisms and ARGs to food is complex. Food can be contaminated with AMR bacteria and/or ARGs in several ways (Verraes et al., 2013; Food Standards Agency, 2016) including (but not exclusively):

1. Through contamination with AMR bacteria in the environment.

2. Through the presence of AMR bacteria on food treated by antimicrobials during agricultural production.

3. The possible presence of ARGs in bacteria that are intentionally added during the processing of food (starter cultures, probiotics, bio-conserving microorganisms and bacteriophages).

4. Through cross-contamination with AMR bacteria and ARGs during food processing.

ARGs in AMR bacteria can be transferred to other surrounding bacteria through Horizontal Gene Transfer (HGT), as will be discussed later. Thus, commensal nonpathogenic AMR bacteria can act a reservoir for ARGs and transfer resistance to non-resistant human pathogenic bacteria (Bengtsson-Palme, 2017). HGT is enhanced by mobile genetic elements (MGEs), such as plasmids, integrons, and transposons, that facilitate the movement, transfer, and integration of genes between cells (Bennett, 2008). ARGs are not always associated with cultivable 'live' bacteria (Error! Reference source not found.). Non-cellular ARGs, which also cover genes 
encapsulated in membrane vesicles (MVs) or bacteriophages, can persist after disinfection, and can transfer to recipient bacteria in the absence of a live donor bacteria (Woegerbauer et al., 2020). The frequency of HGT largely depends on the properties of the MGEs, MVs, or bacteriophages, the characteristics of the donor and recipient populations, and the environment (Verraes et al., 2013; Rossi et al., 2014).

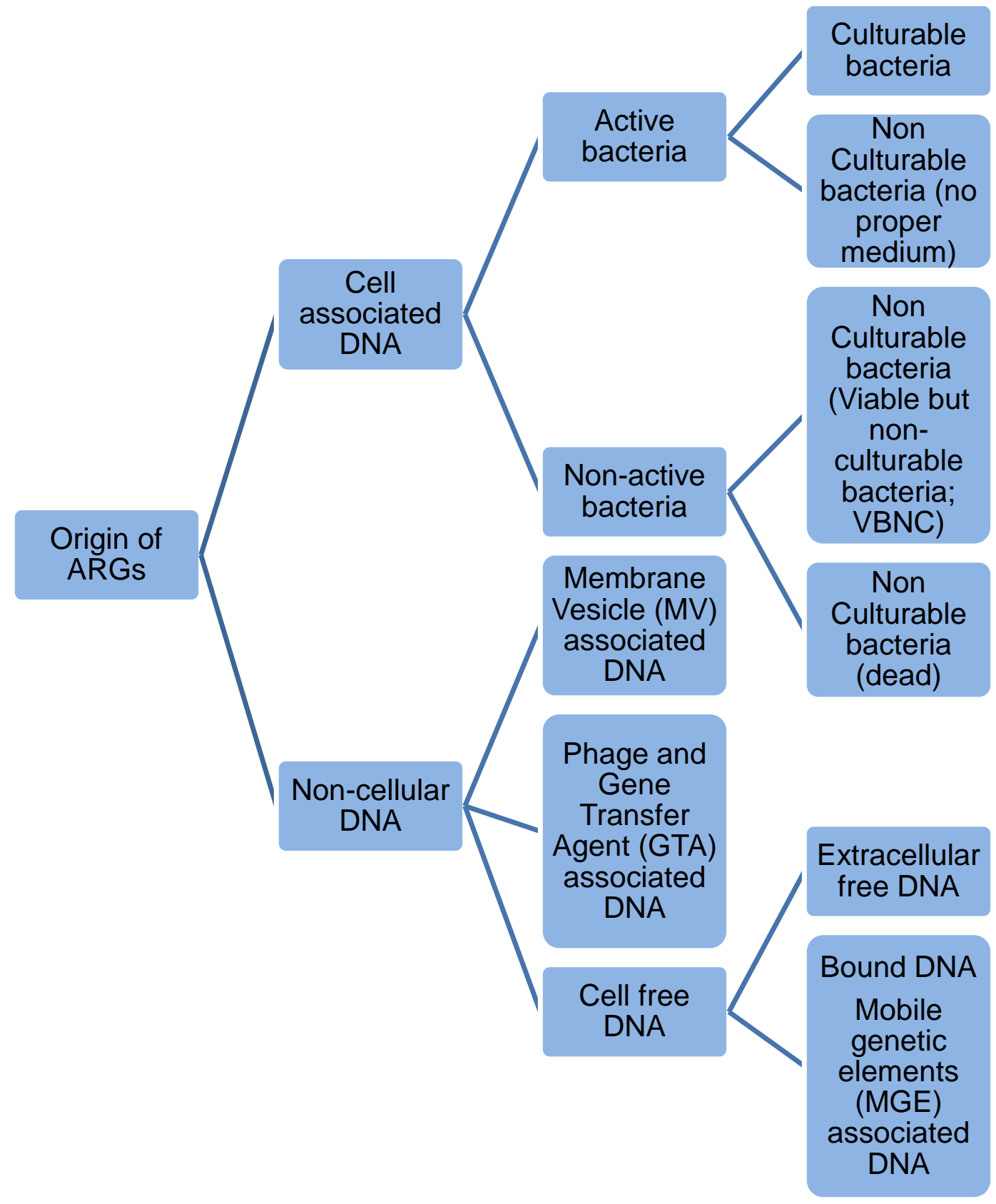

Figure 1. Forms and origins of ARGs quantified by molecular biology approaches (adapted from Woegerbauer et al., 2020) 
There are three main canonical mechanisms of HGT through which this can occur: (1) conjugation, (2) transformation, or (3) transduction. Though, as noted by Hall et al. (2017) and Verraes et al. (2020), amongst others, other less well recognized mechanisms of DNA transfer may occur. These processes are described in detail in reviews such as that by Verraes et al. (2013). Conjugation occurs between live bacterial cells (Verraes et al., 2013) and will not occur if cells are killed by heat, thus this mechanism is not relevant in the context of this review and will not be discussed.

Dead cells cannot use cell-to-cell mechanisms to pass ARGs to other bacteria by conjugation (Verraes et al., 2013), but as soon as DNA fragments have been released after death and lysis, ARGs as extracellular free DNA or facilitated by MGEs may, theoretically, be transferred by transformation (McMahon et al., 2007; Verraes et al., 2013; Le Devendec et al., 2018; Pérez-Rodríguez \& Taban, 2019). It is reported by Lorenz \& Wackernagel (1994) that transformation was first demonstrated by Griffith in 1928, who observed that mice were killed when infected with a mixture of heat-killed pathogenic S-form ("smooth") and living non-pathogenic R-form ("rough") Streptococcus pneumoniae cells. Pneumococci isolated from the cadavers revealed the S-form colony type. Thus, Griffith concluded that the R-form had undergone transformation by the dead S-form. According to Verraes et al. (2013), any bacterial chromosomal or extra-chromosomal DNA can be theoretically transferred by transformation. To be stabilized in the recipient cell, it is reported that the transformed DNA must be available as a plasmid or must recombine with homologous regions in the resident chromosome (Verraes et al., 2013). The overall process of natural genetic transformation can be broken down into six major steps, as described by Lorenz \& Wackernagel (1994) and Huddleston (2014): (1) DNA is released from donor cells; (2) DNA is dispersed; (3) DNA persists in the environment; (4) recipient cells become competent for DNA uptake; (5) competent cells interact with and take up the DNA, incorporating it into the genome either through homologous or illegitimate recombination; and finally (6) genes encoded on the donor DNA are expressed in the recipient cell. 
Natural transformation is known to occur in more than 60 bacterial species, and probably far more (Rossi et al., 2014). The general consensus in the literature is that the process of transformation occurs at low frequency and is subject to a large number of requirements mostly observed in very controlled laboratory conditions (Lorenz \& Wackernagel, 1994; Verraes et al., 2013; von Wintersdorff et al., 2016). Few investigations have expressly analysed exogenous DNA uptake by bacteria in food (Rossi et al., 2014).

There is evidence that DNA stability is an inverse function of DNA length (Kharazmi et al., 2003). Kharazmi et al. (2003) carried out an in vitro mimic of production processes for soya milk, tofu, corn masa, and cooked potato on the degradation of plant DNA in which genetically modified (GM) potatoes with the AMR nptll gene, which encodes kanamycin resistance, as a marker was used. Cooking of potatoes $\left(80^{\circ} \mathrm{C}\right.$ for $\left.1 \mathrm{~h}\right)$ resulted in a strong degradation of the nptll gene.

Studies to transform, by electroporation, Bacillus subtilis LTH 5466, using nptll gene fragments similar to those measured after cooking of the potatoes (but not using the heat-treated fragments) showed that smaller fragments resulted in lower transformation frequencies, while plasmids containing the fragments resulted in greater transformation frequencies. This study provides evidence that although heat treatments will degrade lysed ARGs, extracellular free DNA fragments may still be of sufficient length to be transformed by other bacteria.

As already mentioned, there is third mechanism of HGT, transduction, which is a transfer process mediated by bacteriophage and similar related particles, called Gene Transfer Agents (GTAs) (Verraes et al., 2013). Often shorted to phage, a bacteriophage is a virus that parasitises a bacterium. Phages are capable of packaging part of their host's genetic material (including ARGs) either by reproducing within the host cell before lysing the cell (lytic) or through incorporation into the host cell genome (lysogenic). GTAs are host-cell produced particles that resemble bacteriophage structures. The mechanism of how bacteriophages/GTAs promote the transfer of ARGs is described, amongst others, by Colavecchio et al. 
(2017) and Jebri et al. (2020). The overall process of transduction can be broken down into eight major steps, as described by Bennett et al. (2004): (1) phage particle attaches to cell via specific surface receptor; (2) phage genomic DNA injected into bacterial cell; (3) phage DNA replicated and host genome fragmented; (4) new phage particles assembled, including transducing particles containing host cell DNA fragments in place of phage genome; (5) host cell lysed and new phage particles released; (6) transducing particle attaches to new bacterial host; (7) bacterial DNA fragment injected into new host cell; and finally (8) injected DNA sequences rescued by homologous recombination.

There is a realisation that phages/GTAs may be significant vectors in the transmission of ARGs through the transduction mechanism (Colavecchio et al., 2017; Jebri et al., 2020). Though, as highlighted by Colavecchio et al. (2017), there is considerable debate on their importance. Although phages have been believed to be host-specific there is increasing evidence that phages can have broader host ranges (Jebri et al., 2020). As noted by Colavecchio et al. (2017) and Jebri et al. (2020), the occurrence of phages/GTAs harbouring ARGs has been reported in different food and animal matrices.

Notably Gómez-Gómez et al. (2019) detected six ARGs (blaтем, blactх-M-1, blactх-м-9, blaoxA-48, blavim, and sul1) in DNA extracted from phage particles from ready-to-eat (RTE) samples of ham and sul1 in mortadella purchased from a local retailer. Only five samples of each meat were analysed. sul1 (which encodes sulfonamide resistance) was only detected in one sample of mortadella, though blactX-M-1 (which encodes resistance to extended-spectrum cephalosporin) was detected in four out of the five samples of ham. Though the meat was cooked it must be stressed that the authors did not associate this presence with survival following thermal processing, but rather post-processing cross-contamination. Nevertheless, the survival of phage containing ARGs following heat treatment cannot be ruled out.

As noted by Sommer et al. (2019) there is clear evidence that phages can show a degree of thermal stability and in some cases may survive heat treatments that are 
sufficient to kill target bacteria. The survival of thermal-stable lactococcal phages in pasteurised milk is a long-recognised problem (Murphy et al., 2013). Another example of a heat-tolerant phage has been reported by Lee et al. (2016), who reported that while HY01 (a phage infecting E. coli O157:H7 and Shigella flexneri) was inactivated when incubated at temperatures above $70^{\circ} \mathrm{C}$, it did show stability (though reduced in comparison with $50^{\circ} \mathrm{C}$ ) when incubated at $65^{\circ} \mathrm{C}$ for 12 hours.

Ahmadi et al. (2017) reported that while exposure to $71^{\circ} \mathrm{C}$ for $30 \mathrm{~s}$ reduced Listeria phages P100 below the limit of detection, and $A 511$ from $10^{8}$ to $10^{5} \mathrm{PFU} \mathrm{mL} \mathrm{m}^{-1}$, the P100 phage partly reconstituted to $10^{3}$ PFU $\mathrm{mL}^{-1}$ after cooling.

Jebri et al. (2020) theorised that phages surviving processing methods could be "a reservoir of $A R G$ s that might be transduced to host bacteria occurring in [the] human gut once [RTE] food is consumed."

A further route of transfer that is receiving attention is membrane vesicle (MV) mediated HGT (Woegerbauer et al., 2020). MVs are proteo-liposomal nanoparticles produced by both Gram-negative and Gram-positive bacteria generally in response to environmental stresses (Caruana \& Walper, 2020). They have diverse functions, including the transport of virulence factors, DNA transfer (including ARGs), interception of bacteriophages, antibiotics and eukaryotic host defence factors, cell detoxification and bacterial communication (Toyofuku et al., 2019).

MVs were first found to originate in the outer membrane of Gram-negative bacteria and therefore often called outer-membrane vesicles (OMVs). Recent work has shown that different types of MVs also exist and hence the inclusive term MV is preferred (Toyofuku et al., 2019; Woegerbauer et al., 2020), and used in this report.

Studies have found the presence of DNA of chromosomal, plasmid, and phage origin incorporated into MVs (Uddin et al., 2020). MVs have been found to transfer ARGs between bacterial species (Kulkarni et al., 2015; Wagner et al., 2018; Uddin et al., 
2020). While MV-mediated HGT has been demonstrated according to Woegerbauer et al. (2020), its occurrence in the environment has been largely unexplored.

Woegerbauer et al. (2020) observed that "(i) MVs are produced by numerous bacteria, (ii) they can transport any kind of DNA (including ARGs), (iii) with a membrane fusion-based mechanisms for MV-assisted DNA transformation, no taxonomic limitation are expected regarding the DNA uptake process, (iv) maintaining the acquired DNA in bacterial cell is likely to meet the same limitations as for natural transformation, and (v) the budding process is favoured in antibioticstress environments".

Reviews of ARG exchange in the gut have been carried out (such as Schjørring \& Krogfelt, 2011; Broaders et al., 2013; Huddleston, 2014; Lerner et al., 2017; Mclnnes et al., 2020), but whether ARGs from heat-treated foods can be a source of transfer has not been discussed.

It is fully accepted that for heat treatments such as sterilization, ultra-high temperature (UHT) treatment, and (full) pasteurization under well-defined time/temperature combinations will eradicate /kill vegetative bacterial cells, including those of AMR bacteria. Industrial, food service, domestic or institutional cooking is normally sufficient to eliminate the effect of pathogens from food, but it remains unclear whether thorough cooking destroys all components of AMR bacteria or ARGs. To what extent 'complete' ARG DNA or even fragments of bacterial DNA that survive from chromosomal or plasmid DNA may be capable of transfer to other microbiota in the human gut and be incorporated to become a functional source of a novel bacterial genome is unknown. There is some literature (Aubry-Damon et al., 2004; Hart et al., 2006; Ramchandani et al., 2005) that lends weight to this hypothesis. This is one area that appears to have escaped scrutiny. This review attempts to assess the impact of heat treatments on ARGs that may be present in heat-killed foodborne bacteria and their potential uptake by surrounding viable bacteria in the other foods and the human gut. 


\subsection{Review question and focus of the review}

The review question was:

"Do different heat treatments applied to eliminate bacterial contamination in foods also induce sufficient damage to ARGs to prevent or inhibit their uptake by surrounding viable bacteria present in other settings, including the human gut and other foods?"

The review was structured and aimed at addressing the following key elements:

- To identify and critically review what scientific evidence is available to clarify whether heat treatments of food at a level which eliminates bacterial contamination induces sufficient damage to ARGs to prevent their uptake by surrounding viable bacteria present in other settings including the human gut and other foods.

- To include not only clinically important ESKAPE (Enterococcus faecium, Staphylococcus aureus, Klebsiella pneumoniae, Acinetobacter baumannii, Pseudomonas aeruginosa, and Enterobacter species) and other pathogenic organisms with AMR/industrial relevance (such as Enterobacter species, Enterococcus faecalis, Listeria species, and Salmonella species), but also non-pathogenic AMR microbiota (such as commensal Escherichia coli).

If evidence was found to the primary review question in the identified literature, then the further questions to be answered were:

- Is there compelling evidence to show that heat completely destroys DNA (particularly ARGs either as extracellular free DNA or within AMR bacteria)? What evidence is there of thermal degradation of DNA in various contexts.

- Can heat-treated or damaged DNA (ARGs being the focus) originating from dead bacteria be taken up by live bacteria? General information relating to whether heat treatment of DNA and particularly ARGs (including those on MGEs - e.g., plasmids/transposons, integrons) affects its ability to be taken up by viable bacteria will be obtained, ideally within a food context. 
Information relating to transformation frequencies of heat-treated/damaged DNA versus intact DNA will also be considered.

- What is the impact of different heat treatments on ARG uptake by viable bacteria? Literature will be considered on the effects of bacterial DNA (with a focus on ARGs) exposure to different heat treatments and subsequent effects on uptake of this DNA by viable bacterial cells. MGEs will also be considered. If the literature does not contain such detailed information (e.g., time/temperature combinations), any information obtained will be contextualised in terms of food, e.g., cooking conditions, where possible. Milder heat treatments such as low temperature sous vide, flash frying, slow cooker, and rare or light cooking, will also be considered.

- Is there any evidence of uptake of heat damaged DNA (particularly ARGs) by pathogenic and non-pathogenic bacteria? If this evidence is not directly related to the food/gut environment it will be contextualised where possible. The review will focus on the resistance genes relating to the Critically Important Antimicrobials (CIAs), where possible.

- If the literature provides some indication that heat-damaged DNA (particularly ARGs) can be taken up by naturally or induced competent viable bacteria in the laboratory, then is there any information to suggest that this can also occur in complex environments (e.g., in the presence of large, diverse microbial communities such as the human gut, or complex media such as food (including combined foods) or on food contact materials or biofilms)?

- Is there any evidence to suggest that the behaviour of chromosomal DNA and plasmid DNA in response to heat differs? ARGs of most concern are likely to be the transferable, plasmid-encoded genes.

- Is there any evidence on the role of proteins in the transfer of ARGs from AMR bacteria subjected to heat treatments? Proteins are more vulnerable to heat than DNA but have multiple functions and most of the transfer functions will not occur if they have degraded, such as due to heat damage.

- Is there any evidence on the role of MVs in the survival and transfer of ARGs from AMR bacteria subjected to heat treatments? There is some evidence that they could be an important route of survival of plasmids and/or 
chromosomal DNA either naturally or following stress conditions (exposure to antimicrobials). 


\section{Materials and methods}

A systematic review approach was taken to the literature search. Because of the paucity of specific published studies on this topic a narrative critical review approach was taken to the review of the publications identified.

The review question was:

"Do different heat treatments applied to eliminate bacterial contamination in foods also induce sufficient damage to ARGs to prevent or inhibit their uptake by surrounding viable bacteria present in other settings, including the human gut and other foods?"

The key elements of the question (PIO): Population (P), Intervention (I), and Outcome $(\mathrm{O})$, were:

- The population of interest include pathogenic and non-pathogenic AMR bacteria (such as Acinetobacter baumannii, Campylobacter, Enterobacter, Enterococcus faecium and faecalis, commensal Escherichia coli, Klebsiella pneumoniae, Listeria, Salmonella, Staphylococcus aureus, and Pseudomonas aeruginosa) and specifically their ARGs.

- Any heat treatment interventions applied to foods are considered relevant, such as pasteurisation, sterilisation, cooking treatments (e.g., hot air (oven), steam, hot water (boiling, blanching), hot fat or oil (shallow or deep frying), grilling, radiant, dielectric (microwave), extrusion, pressure, retort), and mild heat treatments (e.g., low temperature sous vide, flash frying, slow cooker, rare or light cooking, hot smoking).

- Relevant outcome measures for interventions are: does the intervention induce sufficient damage to ARGs to prevent or inhibit their uptake by surrounding viable bacteria present in other settings including the human gut and other foods. 
All ARGs of immediate or emerging concern, especially in clinical contexts, were considered.

The review adopted a comprehensive search strategy considering all available evidence in the public domain, including peer-reviewed articles, grey literature (e.g., government and industry reports), relevant government reports (e.g., FSA published studies, ACMSF reports), European and International literature (e.g., the EFSA Scientific Opinions, WHO reports) up to May 2021. This included previously published systematic and critical reviews, and risk assessments, as well as primary research.

The primary source databases searched were Web of Science, and PubMed. The searches were restricted to records published from 1990 to end of May 2021. Finalised keywords were agreed with the Agency and were:

antimicrobial resistance $O R$ antimicrobial resistant $O R$ antibiotic resistance $O R$ antibiotic resistant $\mathrm{OR}$ antibacterial resistance $\mathrm{OR}$ antibacterial resistant $\mathrm{OR}$ drug resistant OR multi resistance OR multi resistant OR multidrug resistance OR multidrug resistant $O R$ multi-drug resistance $O R$ multi-drug resistant $O R$ multiantibiotic resistance OR multiantibiotic resistant OR AMR OR MDR OR MAR OR AR OR AMRG

AND

Acinetobacter OR Campylobacter OR commensal OR Enterobacter OR Enterococcus OR Escherichia coli OR E. coli OR Klebsiella OR Listeria OR Salmonella OR Staphylococcus OR pathogen OR Pseudomonas AND

Blanch* OR boil* OR canning OR cook* OR fried OR fry* OR griddle OR grill ${ }^{*}$ OR heat OR "high temperature" OR HTST OR "hot fat" OR "hot fat" OR "hot oil" OR "hot water" OR microwave* OR oven OR pasteuri* OR "pressure cook" OR retorting OR roast OR "sous vide" OR steam OR steili* OR thermal OR UHT 
Focused Google searches were used to identify relevant grey literature. In total 2446 citations were initially identified in Web of Science and 937 were identified in PubMed. There was some overlap between the databases with 737 duplicates. An additional 35 records were identified through Google searches, other references, and through contact with authors. For all searches, citations and abstracts were uploaded from each of the electronic databases into Covidence (an online tool for systematic reviewing). The following exclusion criteria were applied:

(1) The publication did not address the impact of heat treatments on AMR bacteria or genes;

(2) The publication was in a language other than English;

(3) The publication measured irrelevant interventions (no heat treatment), outcomes, or populations or samples.

The criteria were independently applied to the abstract of each paper by at least two members of the five-member project team. For each citation, a consensus was reached that the citation is relevant for inclusion. Arbitration by a third member of the project team was used to settle conflicting appraisals. 2,681 abstracts were screened and 2434 references excluded. Full texts were obtained for all abstracts that passed the inclusion criteria.

A total of 247 publications were considered relevant by title and abstract and full texts collected for second screening. This number was reduced to 53 publications from which some data were extracted, with 194 references being excluded because they were not relevant. Of these publications, nine were reviews with some mention of the impact of heat on AMR bacteria, while 17 had evidence on the relative heat resistance of AMR bacteria in comparison to non-AMR bacteria. Only four publications were identified that were considered to fully meet the search criteria, i.e., had considered the impact of heat treatments on the persistence of ARGs after such treatments. There was an intention to carry out a systematic analysis of publications, but following discussion between reviewers, due to the small number of 
publications and differences in experimental approach between the publications it was considered more useful to fully present what these studies reported. Similarly, due to the lack of necessary statistical descriptors making a comparison of studies not suited to a meta-analysis approach it was considered best to discuss these findings narratively rather than quantitatively. 


\subsection{Flowchart of knowledge synthesis}

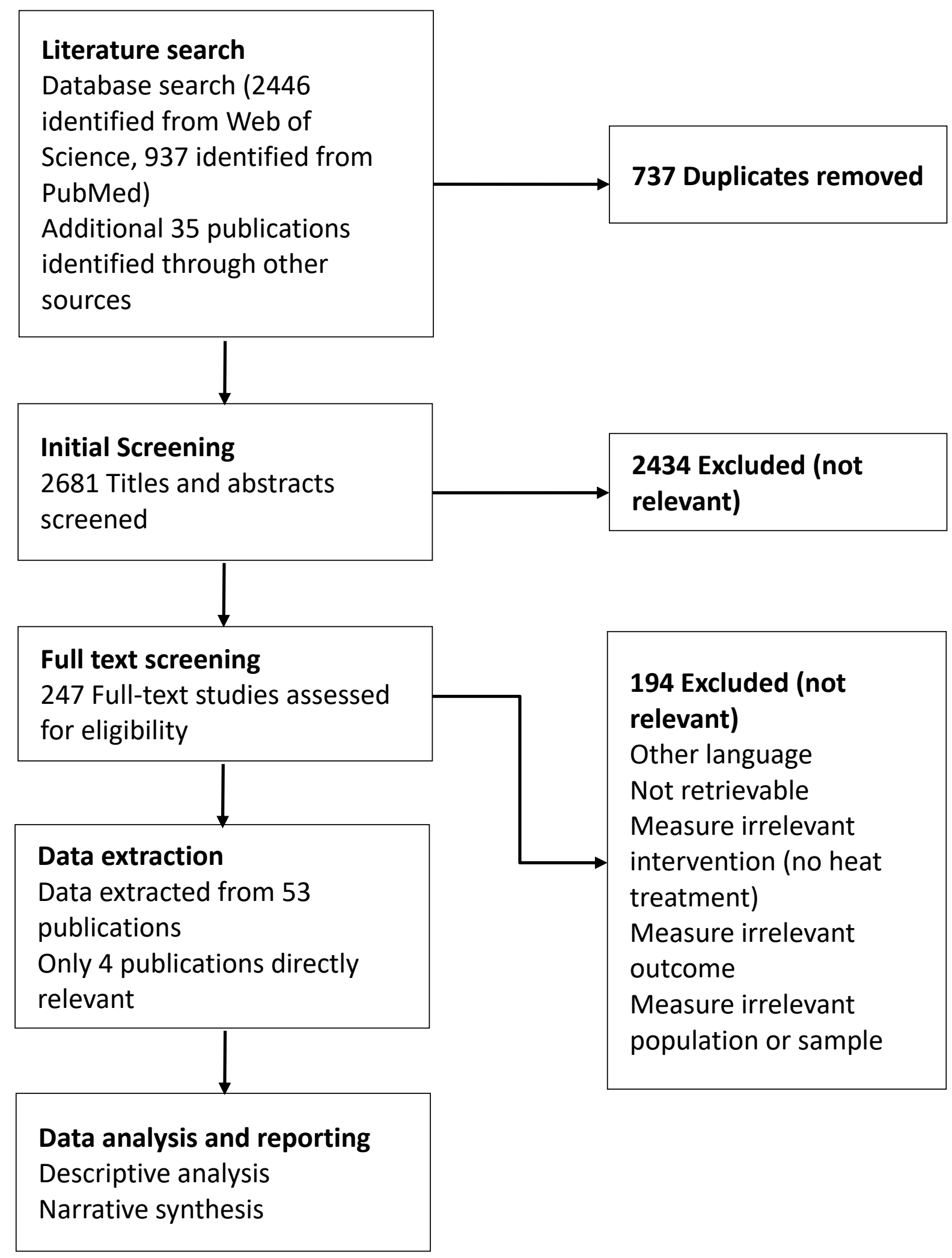




\section{Review of published literature on the impact of heat treatment of food on ARGs}

The literature search identified nine publications in the last decade that in part reviewed aspects of the thermal resistance of AMR bacteria in foods subjected to heat treatments (Verraes et al., 2013; Friedman, 2015; Report of the Scientific Committee of the Food Safety Authority of Ireland, 2015; Zhang \& Wang, 2018; Pérez-Rodríguez \& Taban, 2019; Liao et al., 2020; Bennani et al., 2020; Hutchison et al., 2020; Woode et al., 2020).

The survival of AMR bacteria in insufficiently heat-treated foods, and whether AMR bacteria are more heat resistant than non-AMR bacteria are discussed in part in some of these reviews (Zhang \& Wang, 2018; Liao et al., 2020).

Three of these reviews (Verraes et al., 2013; Report of the Scientific Committee of the Food Safety Authority of Ireland, 2015; Pérez-Rodríguez \& Taban, 2019) mention the theoretical persistence of ARGs after heat treatment. The origin of this theory appears to be Verraes et al. (2013) who note, in the context of the transfer of AMR in the food processing environment, that "food processing and/or preservation techniques can kill or inactivate the bacteria. Those dead bacterial cells can stay intact or can be lysed due to cell wall damage. As a consequence, the bacterial DNA, including the eventual present ARGs, are liberated in the environment." Although none of these publications provide any citations that have demonstrated this.

Liao et al. (2020) provide a fairly comprehensive review of the heat tolerance of AMR bacteria, but does not consider the impact on, or persistence of, ARGs after any heat treatment. Overall, the reviews all find consensus that:

(1) Heat treatments capable of reducing non-AMR bacteria are equally effective in reducing AMR bacteria. 
(2) The presence of AMR bacteria or genes in cooked food after cooking is likely to be the result of insufficient heat treatment or contamination after cooking.

A comprehensive review of the impact of food processing on AMR bacteria in secondary processed meats and meat products found no specific publications describing the fate of AMR bacteria after thermal processing (i.e., cooking) (Hutchison et al., 2020). The authors note that there are reports of cooked meats contaminated with AMR bacteria (and we would also note ARGs), primarily from China (Jiang et al. 2014; Li et al. 2016; Yu et al. 2016; Jiang et al. 2017; Yu et al. 2017).

Hutchison et al. (2020) also noted that these surveys were collected at retail and in foodservice and were unable to determine if the AMR bacteria/genes were detected after effective cooking or cross-contamination. We would also note that similar surveys of pasteurised and sterilised milk report the presence of AMR bacteria/genes, but again may also be post treatment contamination.

The recent work by Taher et al. (2020a, is one of the few studies that have reported that a standard and globally accepted milk pasteurisation treatment $\left(63.5^{\circ} \mathrm{C}\right.$ for 30 $\mathrm{min}$ ) may not be sufficient to inactivate plasmid-mediated ARGs (this is discussed in detail in Section 6.2). The study reveals concerns about inducing a viable but nonculturable (VBNC) state in bacteria.

In addition, as previously discussed in the introduction, Gómez-Gómez et al. (2019) detected ARGs in DNA extracted from phage particles extracted from cooked ham and mortadella. The authors attributed this presence to post treatment contamination, noting that the thermal processing that the ham and mortadella would have eliminated microorganisms. They do not appear to have considered the possibility that ARGs could have persisted in the meat following thermal processing, 
however in our opinion the possibility of persistence after effective cooking cannot be ruled out.

\subsection{Are AMR bacteria more heat-resistant than non-AMR bacteria?}

It is accepted in the literature that heat treatments such as sterilization, ultra-high temperature (UHT) treatment, and (full, traditional) pasteurization under well-defined time/temperature combinations will eradicate/kill vegetative bacterial cells, including AMR bacteria. Industrial, food service, domestic or institutional cooking undertaken correctly is normally sufficient to eliminate bacterial pathogens from food.

Risk assessments of the impact on human health of cooking, such as Anderson et al. (2001), assume "proper handling and cooking of food" can almost entirely eliminate the risk from many pathogens. Such assessments do not address whether ARGs may persist after cooking in a detectable and functional form.

Studies have indicated that foodborne AMR bacteria (such as Escherichia coli, Listeria monocytogenes, Salmonella species, Staphylococcus aureus, Yersinia enterocolitica) do not exhibit enhanced thermal resistance characteristics (see Table 1). Studies on serovars of Salmonella spp. that were AMR or non-AMR by Stopforth et al. (2008) and Bacon et al. (2003) concluded that there was no evidence of any association between antimicrobial susceptibility and the ability of specific serovars to survive or repair damage associated with heat stress. On the other hand, as noted also by Liao et al. (2020), some studies (Doherty et al., 1998; Dombroski et al., 1999; Duffy et al., 2006) provide evidence that AMR may impair thermal tolerance in bacteria. McKay (2008) found that D-values of mecA-positive Staphylococcus spp. at $56^{\circ} \mathrm{C}$ in whole milk were substantially lower than those of methicillin-susceptible S. aureus (MSSA) ( $\max 2.82 \mathrm{~min}$ vs $20.1 \mathrm{~min}$ ) and thus concluded that heat treatments intended to control $S$. aureus should be equally effective at controlling MRSA. 
The majority of published reviews and studies conclude that there is no evidence to suggest that AMR bacteria are more heat-tolerant than non-AMR bacteria, with the exception of one publication by Walsh et al. (2005), which is often cited by reviews and other publications as a contradiction. Although other recent publications such as by Sarjit et al. (2020) and Yehia et al. (2020) also provide evidence that some strains of AMR bacteria may be more thermally-resistant than non-AMR strains. Walsh et al. (2005) reported that an AMR strain, Salmonella enterica serovar Typhimurium definitive phage type (DT) 104 (= S. Typhimurium DT 104) had enhanced thermal tolerance characteristics. This study also found that $S$. Typhimurium DT 104 subjected to a sub-lethal heat shock $\left(48^{\circ} \mathrm{C}\right.$ for $\left.30 \mathrm{~min}\right)$ was significantly more heat-resistant than non-heat-shocked S. Typhimurium DT 104, indicating that heat shocking conferred thermotolerance could be incited in this strain. It must be stressed conferred thermotolerance is not unique to this strain or is related to AMR.

Sarjit et al. (2021a) investigated the impact of a dry heat treatment at $70^{\circ} \mathrm{C}$ for up to an hour on inoculated strains of Salmonella spp. on beef, lamb, and goat meat in the context of a processing CCP intervention step. This study found that a $70^{\circ} \mathrm{C}$ for $1 \mathrm{~h}$ dry heat treatment was less effective than a $70^{\circ} \mathrm{C}$ for 5 min treatment on the same Salmonella strains in a model meat juice system (Sarjit et al., 2021b). Of the Salmonella serovars used, an AMR strain of $S$. Typhimurium 2470 on beef and lamb, and S. Heidelberg (329 and 2581) on lamb were reported as displaying a significant $(p \leq 0.05)$ lower decline in numbers. The authors speculated that AMR "in Salmonella [spp.] may influence its thermal resistance depending on the environmental influence such as a meat matrix and its composition". In our opinion, further trials are required to clearly establish whether there is any association. Yehia et al. (2020) found a high proportion (10\%) of what were identified as heat resistant MRSA isolated from pasteurised camel milk to be more heat resistant than a reference strain S. aureus ATCC 29737, which was used as a control. While heat treatments of $85^{\circ} \mathrm{C}$ and $90^{\circ} \mathrm{C}$ were sufficient to inactivate $S$. aureus ATCC 29737 , the heat resistant MRSA had a mean $D_{85}$ of $111 \mathrm{~s}$, with three isolates being heat resistant even at $90^{\circ} \mathrm{C}$ for 60 or $90 \mathrm{~s}$. This is in contrast to the findings of McKay (2008), as previously reported. 
Few publications have compared the efficacy of heat treatments used as interventions during the processing of red meat and poultry (as used in the USA and other countries) on AMR bacteria. Hughes et al. (2010) reported AMR Salmonella strains to be no more heat-resistant than non-AMR Salmonella strains in heattreated beef, although as previously reported, Sarjit et al. (2021a) found that AMR strains of Salmonella spp. were more heat-resistant than non-AMR strains to a dry heat treatment.

The literature search identified few publications on the impact of commercial thermal processing on AMR bacteria or genes in foods. The survival of MRSA during the thermal processing of frankfurters, summer sausage, and boneless ham was investigated by Campbell et al. (2014). Heating the products to an internal temperature of $70^{\circ} \mathrm{C}$, followed by rapid cooling reduced inoculated MRSA (levels approximately 7.76 to $7.73 \log _{10} \mathrm{CFU} \mathrm{g}^{-1}$ ) in frankfurters, summer sausage, and boneless ham by $5.53,6.75,7.28 \log _{10} \mathrm{CFU} \mathrm{g}{ }^{-1}$, respectively. Since the level of MRSA contamination is reported to be low in these meats, the authors considered the heat treatments to be adequate. There is no mention of consideration of the survival of ARGs or whether the resistance of MRSA is any different to non-AMR bacteria. Conversely, as previously reported Yehia et al. (2020) isolated a high proportion (10\%) of what were identified as heat resistant MRSA from pasteurised camel milk in Saudi Arabia. The authors recommended that heat treatments such as $93.8^{\circ} \mathrm{C}$ for $0.1 \mathrm{~s}, 96.2^{\circ} \mathrm{C}$ for $0.05 \mathrm{~s}$, or $100^{\circ} \mathrm{C}$ for $0.01 \mathrm{~s}$, be used to destroy the contaminating heat resistance MRSA. The literature search only identified one publication on the impact of dielectric heating (microwave or radio frequency [RF]). Rincón \& Singh (2016) evaluated the use of nalidixic acid-resistant strains of three major Shiga toxin-producing E. coli (STEC) and non-pathogenic E. coli for use as marker organisms to challenge test the effectiveness of RF heat treatments. They concluded that the heat resistance of nalidixic acid-resistant strains were not significantly different to nalidixic acid-sensitive strains at the endpoint temperatures investigated $\left(55,60\right.$, and $\left.65^{\circ} \mathrm{C}\right)$. 
While there are many publications on the thermal inactivation of bacteria (particularly pathogens) during a wide variety of cooking operations, especially regarding the gridling of burgers (patties) and steaks, the literature search identified no publications on the possible impact of different domestic or foodservice cooking methods specifically on AMR bacteria.

As noted by Walsh et al. (2005) laboratory-acquired AMR strains of bacteria are often used as "marker" strains for use in process validation experiments. Prior to their use their heat resistance is usually compared with non-AMR strains to establish their fitness for such purpose and that their heat resistance is similar to but not greater than the target organism (examples being Foeging \& Stanley, 1991; Shen et al., 2011; Luchansky et al., 2014).

We would agree with comments of Lianou \& Koutsoumanis (2013) that in addition to bacterial species and strains, many other factors may have a significant impact on the heat resistance of bacteria, whether AMR or non-AMR. Such factors include the growth conditions, growth phase, and lineage of the cultures to be tested, the type and composition of the medium used (food matrix or various laboratory medium), the challenge conditions (e.g., temperature and $\mathrm{pH}$ of challenge media, type of acidulant), the presence of competing microflora, and the procedures and recovery media used for determination of bacterial survival.

Overall, the publications identified in the literature search provide evidence that there are differences in thermal tolerance between different bacteria species, serotypes, or strains, and different substrates. None of these publications on the comparative heat resistance of AMR bacteria provide evidence of whether ARGs may survive such treatments or even express a concern on whether ARGs survive the heat processes applied. The few publications that have been identified that have addressed the survival of ARGs following heat treatments are discussed in detail in the next section of this report. 
A number of reviews note that increased use of sub-lethal, rather than lethal, food preservation heat treatments may be more important than was previously considered for the development and dissemination of AMR bacteria and genes (Verraes et al., 2013; Capita \& Alonso-Calleja, 2013; Ferri et al., 2017; Pérez-Rodríguez \& Mercanoglu Taban, 2019; Liao et al., 2020). They note that mild heat treatments $\left(45-60^{\circ} \mathrm{C}\right)$ may be ineffective in inactivating both $A M R$ and non-AMR microorganisms and could trigger bacterial stress responses. None of these reviews cite published evidence of what impact "mild heat treatments" could have on ARGs and the literature search did not identify further clear evidence on this risk.

There is evidence that stress conditions (such as heat stress) may trigger several mechanisms in bacterial cells, e.g., stress adaptation, cellular repair, application of response mechanisms and enhanced virulence (Wesche et al., 2009). In their review of sub-lethal injury Wesche et al. (2009) noted that thermal treatments that included an extended "come-up phase", such as slow roasting of meats, or certain sous-vide processes, might cause sub-lethal injury to microorganisms. The literature search identified only two studies on the impact of sub-lethal heat treatment on AMR bacteria. McMahon et al. (2007) reported that incubation at a sub-lethal temperature $\left(45^{\circ} \mathrm{C}\right.$; no time was stated) increased the antimicrobial susceptibility, determined using minimum inhibitory concentration (MIC) tests, of strains of E. coli (ec1, ec2, ec3, and ec5) to amikacin, ceftriaxone, and nalidixic acid, S. Typhimurium DT 104 (st11, st12, st 16, and st17) to amikacin, ceftriaxone, and trimethoprim, and S. aureus (sa3, sa4, sa5, and sa6) to amikacin, ceftriaxone, trimethoprim. Although on the other hand incubation under increased salt $(>4.5 \%)$ or reduced $\mathrm{pH}(<5.0)$ conditions increased resistance. Some of the bacteria subjected to low-pH and high salt stress also continued to show higher levels of resistance after removal of the stress, indicating stable increases in AMR. As previously noted, in contrast the study by Walsh et al. (2005) found that heat shocking $\left(48^{\circ} \mathrm{C}\right.$ for $\left.30 \mathrm{~min}\right)$ conferred thermotolerance in S. Typhimurium DT 104. 
Table 1. A summary of studies that have compared the heat resistance of Antimicrobial resistance (AMR) and non-AMR bacteria (adapted from Liao et al., 2020 and expanded)

\begin{tabular}{|c|c|c|c|c|c|c|}
\hline $\begin{array}{l}\text { Evaluation } \\
\text { temperature } \\
\left({ }^{\circ} \mathrm{C}\right)\end{array}$ & Medium & $\begin{array}{l}\text { Species and } \\
\text { strains }\end{array}$ & $\begin{array}{l}\text { Enhanced } \\
\text { thermal } \\
\text { resistance }\end{array}$ & $\begin{array}{l}\text { Stated antimicrobial } \\
\text { resistance profiles } \\
\text { (antimicrobial or class) }\end{array}$ & $\begin{array}{l}\text { Antimicrobial } \\
\text { Resistance } \\
\text { Genes (ARGs) } \\
\text { present }\end{array}$ & Reference \\
\hline $50-60$ & $\begin{array}{l}\text { Minced } \\
\text { beef and } \\
\text { potato }\end{array}$ & $\begin{array}{l}\text { Y. enterocolitica } \\
\text { L. monocytogenes }\end{array}$ & No & Nalidixic acid & NS & Doherty et al. (1998) \\
\hline 47 & Oysters & Vibrio vulnificus & No & Nalidixic acid & NS & $\begin{array}{l}\text { Dombroski et al. } \\
\text { (1999) }\end{array}$ \\
\hline 54,82 & $\begin{array}{l}\text { Egg white } \\
\text { powder }\end{array}$ & $\begin{array}{l}\text { S. Typhimurium } \\
\text { DT104 } \\
\text { Non-DT104 S. } \\
\text { Typhimurium }\end{array}$ & No & NS & NS & $\begin{array}{l}\text { Jung \& Beuchat } \\
\text { (1999) }\end{array}$ \\
\hline $\begin{array}{l}51,53,55, \\
57,59,61\end{array}$ & $\begin{array}{l}\text { Liquid } \\
\text { whole egg, } \\
\text { egg yolk, } \\
\text { egg white, } \\
\text { whole egg }\end{array}$ & $\begin{array}{l}\text { S. Typhimurium } \\
\text { DT104 } \\
\text { Non-DT104 S. } \\
\text { Typhimurium }\end{array}$ & No & $\begin{array}{l}\text { NS, but strains of DT104 } \\
\text { quoted as being resistant } \\
\text { to ampicillin, } \\
\text { chloramphenicol } \\
\text { streptomycin, }\end{array}$ & NS & $\begin{array}{l}\text { Jung \& Beuchat } \\
\text { (2000) }\end{array}$ \\
\hline
\end{tabular}




\begin{tabular}{|c|c|c|c|c|c|c|}
\hline $\begin{array}{l}\text { Evaluation } \\
\text { temperature } \\
\left({ }^{\circ} \mathrm{C}\right)\end{array}$ & Medium & $\begin{array}{l}\text { Species and } \\
\text { strains }\end{array}$ & $\begin{array}{l}\text { Enhanced } \\
\text { thermal } \\
\text { resistance }\end{array}$ & $\begin{array}{l}\text { Stated antimicrobial } \\
\text { resistance profiles } \\
\text { (antimicrobial or class) }\end{array}$ & $\begin{array}{l}\text { Antimicrobial } \\
\text { Resistance } \\
\text { Genes (ARGs) } \\
\text { present }\end{array}$ & Reference \\
\hline & 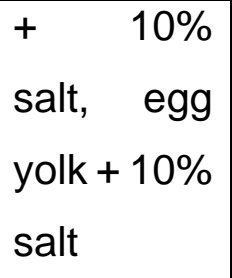 & & & $\begin{array}{l}\text { sulphonamides, } \\
\text { tetracyclines }\end{array}$ & & \\
\hline 55 & $\begin{array}{l}\text { Minced } \\
\text { beef and } \\
\text { potato }\end{array}$ & L. monocytogenes & No & Streptomycin & NS & Walsh et al. (2001) \\
\hline $55,57,59,61$ & $\begin{array}{l}\text { Tryptic soy } \\
\text { broth } \\
\text { (TSB) }\end{array}$ & $\begin{array}{l}\text { Salmonella spp } \\
\text { serovars } \\
\text { Saint-Paul, } \\
\text { Anatum, } \\
\text { Mbandaka, Agona, } \\
\text { Reading, } \\
\text { Typhimurium } \\
\text { (DT104) }\end{array}$ & No & $\begin{array}{l}\text { Ampicillin, } \\
\text { chloramphenicol, } \\
\text { streptomycin, } \\
\text { sulphonamides, and } \\
\text { tetracycline, amoxicillin- } \\
\text { clavulanic acid, } \\
\text { ampicillin-sulbactam, } \\
\text { gentamicin, trimethoprim- } \\
\text { sulfamethoxazole }\end{array}$ & NS & Bacon et al. (2003) \\
\hline
\end{tabular}




\begin{tabular}{|c|c|c|c|c|c|c|}
\hline $\begin{array}{l}\text { Evaluation } \\
\text { temperature } \\
\left({ }^{\circ} \mathrm{C}\right)\end{array}$ & Medium & $\begin{array}{l}\text { Species and } \\
\text { strains }\end{array}$ & $\begin{array}{l}\text { Enhanced } \\
\text { thermal } \\
\text { resistance }\end{array}$ & $\begin{array}{l}\text { Stated antimicrobial } \\
\text { resistance profiles } \\
\text { (antimicrobial or class) }\end{array}$ & $\begin{array}{l}\text { Antimicrobial } \\
\text { Resistance } \\
\text { Genes (ARGs) } \\
\text { present }\end{array}$ & Reference \\
\hline & & & & $\begin{array}{l}\text { Depending on serotype } \\
\text { or strain }\end{array}$ & & \\
\hline 55 & $\begin{array}{l}\text { Chicken } \\
\text { pieces }\end{array}$ & $\begin{array}{l}\text { S. Typhimurium } \\
\text { DT104 }\end{array}$ & Yes & $\begin{array}{l}\text { Ampicillin, streptomycin, } \\
\text { sulphonamides, } \\
\text { chloramphenicol, } \\
\text { tetracyclines }\end{array}$ & NS & Walsh et al. (2005) \\
\hline 55 & $\begin{array}{l}\text { Chicken } \\
\text { pieces }\end{array}$ & $\begin{array}{l}\text { S. Enteritidis } \\
\text { S. Typhimurium }\end{array}$ & No & $\begin{array}{l}\text { Nalidixic acid, } \\
\text { streptomycin }\end{array}$ & NS & Walsh et al. (2005) \\
\hline 55 & $\begin{array}{l}\text { Minced } \\
\text { beef }\end{array}$ & $\begin{array}{l}\text { E. coli O157:H7, } \\
\text { O26 }\end{array}$ & No & $\begin{array}{l}\text { Ampicillin, kanamycin, } \\
\text { streptomycin, } \\
\text { trimethoprim, nalidixic } \\
\text { acid, rifampicin, } \\
\text { sulphonamides, } \\
\text { chloramphenicol, } \\
\text { tetracycline, minocycline, } \\
\text { doxycycline }\end{array}$ & NS & Duffy et al. (2006) \\
\hline
\end{tabular}




\begin{tabular}{|c|c|c|c|c|c|c|}
\hline $\begin{array}{l}\text { Evaluation } \\
\text { temperature } \\
\left({ }^{\circ} \mathrm{C}\right)\end{array}$ & Medium & $\begin{array}{l}\text { Species and } \\
\text { strains }\end{array}$ & $\begin{array}{l}\text { Enhanced } \\
\text { thermal } \\
\text { resistance }\end{array}$ & $\begin{array}{l}\text { Stated antimicrobial } \\
\text { resistance profiles } \\
\text { (antimicrobial or class) }\end{array}$ & $\begin{array}{l}\text { Antimicrobial } \\
\text { Resistance } \\
\text { Genes (ARGs) } \\
\text { present }\end{array}$ & Reference \\
\hline & & & & $\begin{array}{l}\text { Depending on serotype } \\
\text { or strain }\end{array}$ & & \\
\hline $55,60,65,70$ & $\begin{array}{l}\text { Tryptic soy } \\
\text { broth } \\
\text { (TSB) }\end{array}$ & $\begin{array}{l}\text { Salmonella spp. } \\
\text { serovars } \\
\text { Montevideo } \\
\text { Typhimurium, } \\
\text { Anatum, } \\
\text { Muenster, } \\
\text { Newport, } \\
\text { Mbandaka, } \\
\text { Dublin } \\
\text { Reading, } \\
\text { Agona, } \\
\text { Give }\end{array}$ & No & $\begin{array}{l}\text { Ampicillin, } \\
\text { chloramphenicol, } \\
\text { streptomycin, } \\
\text { sulphonamides, } \\
\text { tetracycline, amoxicillin- } \\
\text { clavulanic acid, } \\
\text { kanamycin, } \\
\text { sulphamethoxazole- } \\
\text { trimethoprim, gentamicin }\end{array}$ & NS & $\begin{array}{l}\text { Stopforth et al. } \\
(2008)\end{array}$ \\
\hline 56 & $\begin{array}{l}\text { Whole } \\
\text { milk }\end{array}$ & $\begin{array}{l}\text { mecA-carrying } \\
\text { Staphylococcus }\end{array}$ & No & $\begin{array}{l}\text { Tetracycline, kanamycin, } \\
\text { spectinomycin, }\end{array}$ & mecA & McKay (2008) \\
\hline
\end{tabular}




\begin{tabular}{|c|c|c|c|c|c|c|}
\hline $\begin{array}{l}\text { Evaluation } \\
\text { temperature } \\
\left({ }^{\circ} \mathrm{C}\right)\end{array}$ & Medium & $\begin{array}{l}\text { Species and } \\
\text { strains }\end{array}$ & $\begin{array}{l}\text { Enhanced } \\
\text { thermal } \\
\text { resistance }\end{array}$ & $\begin{array}{l}\text { Stated antimicrobial } \\
\text { resistance profiles } \\
\text { (antimicrobial or class) }\end{array}$ & $\begin{array}{l}\text { Antimicrobial } \\
\text { Resistance } \\
\text { Genes (ARGs) } \\
\text { present }\end{array}$ & Reference \\
\hline & & $\begin{array}{l}\text { spp. strains (S. } \\
\text { epidermidis, } \\
\text { haemolyticus, } \\
\text { lentus) }\end{array}$ & & $\begin{array}{l}\text { erythromycin, } \\
\text { trimethoprim, } \\
\text { sulphamethoxazole- } \\
\text { trimethoprim } \\
\text { Depending on serotype } \\
\text { or strain }\end{array}$ & & \\
\hline 57 & $\begin{array}{l}\text { Tryptic soy } \\
\text { broth } \\
\text { (TSB-G) }\end{array}$ & $\begin{array}{l}60 \text { Salmonella } \\
\text { spp. serovars } \\
\text { including: } \\
\text { Typhimurium (18 } \\
\text { strains), Enteritidis } \\
\text { (10 strains), } \\
\text { Newport ( } 9 \\
\text { strains), } \\
\text { Heidelberg (8 } \\
\text { strains), } \\
\text { Montevideo (4 }\end{array}$ & No & NS & NS & $\begin{array}{l}\text { Lianou \& } \\
\text { Koutsoumanis } \\
(2013)\end{array}$ \\
\hline
\end{tabular}




\begin{tabular}{|c|c|c|c|c|c|c|}
\hline $\begin{array}{l}\text { Evaluation } \\
\text { temperature } \\
\left({ }^{\circ} \mathrm{C}\right)\end{array}$ & Medium & $\begin{array}{l}\text { Species and } \\
\text { strains }\end{array}$ & $\begin{array}{l}\text { Enhanced } \\
\text { thermal } \\
\text { resistance }\end{array}$ & $\begin{array}{l}\text { Stated antimicrobial } \\
\text { resistance profiles } \\
\text { (antimicrobial or class) }\end{array}$ & $\begin{array}{l}\text { Antimicrobial } \\
\text { Resistance } \\
\text { Genes (ARGs) } \\
\text { present }\end{array}$ & Reference \\
\hline & & $\begin{array}{l}\text { strains), } \\
\text { Senftenberg (4 } \\
\text { strains), Agona (3 } \\
\text { strains), Infantis (3 } \\
\text { strains) and Derby } \\
\text { (1 strain). }\end{array}$ & & & & \\
\hline $60,61,62.5$ & $\begin{array}{l}\text { Tryptic soy } \\
\text { broth } \\
\text { (TSB) }\end{array}$ & $\begin{array}{l}\text { E. coli (STEC) } \\
\text { serotypes O26 } \\
\text { and } \mathrm{O} 103\end{array}$ & No & $\begin{array}{l}\text { Ampicillin, penicillin, } \\
\text { ceftiofur, spectinomycin, } \\
\text { oxytetracycline, } \\
\text { clindamycin, } \\
\text { sulphadimethoxime, } \\
\text { tiamulin, tilmicosin, } \\
\text { tetracycline } \\
\text { Depending on serotype } \\
\text { or strain }\end{array}$ & $\begin{array}{l}\text { stx1, stx2, } \\
\text { eaeA, hylA * }\end{array}$ & Akhtar et al. (2016) \\
\hline
\end{tabular}




\begin{tabular}{|c|c|c|c|c|c|c|}
\hline $\begin{array}{l}\text { Evaluation } \\
\text { temperature } \\
\left({ }^{\circ} \mathrm{C}\right)\end{array}$ & Medium & $\begin{array}{l}\text { Species and } \\
\text { strains }\end{array}$ & $\begin{array}{l}\text { Enhanced } \\
\text { thermal } \\
\text { resistance }\end{array}$ & $\begin{array}{l}\text { Stated antimicrobial } \\
\text { resistance profiles } \\
\text { (antimicrobial or class) }\end{array}$ & $\begin{array}{l}\text { Antimicrobial } \\
\text { Resistance } \\
\text { Genes (ARGs) } \\
\text { present }\end{array}$ & Reference \\
\hline $\begin{array}{l}55,60,65 \\
\text { (Radio } \\
\text { Frequency } \\
\text { heating) }\end{array}$ & $\begin{array}{l}\text { Phosphate } \\
\text { buffer } \\
\text { saline } \\
\text { (PBS) }\end{array}$ & $\begin{array}{l}\text { E. coli (STEC) } \\
\text { serotypes } \\
\text { O157:H7, } \\
\text { O26:H11, O11 }\end{array}$ & No & Nalidixic acid & NS & $\begin{array}{l}\text { Rincon \& Singh } \\
(2016)\end{array}$ \\
\hline 58 & $\begin{array}{l}\text { Ringer's } \\
\text { solution }\end{array}$ & L. monocytogenes & No & $\begin{array}{l}\text { Erythromycin, } \\
\text { ciprofloxacin, } \\
\text { nitrofurantoin * }\end{array}$ & NS & Komora et al. (2017) \\
\hline 63 & $\begin{array}{l}\text { Saline } \\
\text { solution }\end{array}$ & S. aureus & No & $\begin{array}{l}\text { Ciprofloxacin, } \\
\text { chloramphenicol, } \\
\text { erythromycin, penicillin, } \\
\text { sulfamethoxazole, } \\
\text { clindamycin, tetracycline, } \\
\text { oxacillin, cefoxitin, } \\
\text { gentamicin ciprofloxacin } \\
\text { Depending on serotype } \\
\text { or strain }\end{array}$ & $\begin{array}{l}\text { sul1, sul2, sul3, } \\
\text { tetA, tetB, tetC, } \\
\text { tetM, } \\
\operatorname{aac(6))/aph~(2"),~} \\
\operatorname{mecA} \text { femA, } \\
\text { ermA, ermC, } \\
\text { norA, cat1, } \\
\text { cmIA, flor * }\end{array}$ & Ma et al. (2019) \\
\hline
\end{tabular}




\begin{tabular}{|c|c|c|c|c|c|c|}
\hline $\begin{array}{l}\text { Evaluation } \\
\text { temperature } \\
\left({ }^{\circ} \mathrm{C}\right)\end{array}$ & Medium & $\begin{array}{l}\text { Species and } \\
\text { strains }\end{array}$ & $\begin{array}{l}\text { Enhanced } \\
\text { thermal } \\
\text { resistance }\end{array}$ & $\begin{array}{l}\text { Stated antimicrobial } \\
\text { resistance profiles } \\
\text { (antimicrobial or class) }\end{array}$ & $\begin{array}{l}\text { Antimicrobial } \\
\text { Resistance } \\
\text { Genes (ARGs) } \\
\text { present }\end{array}$ & Reference \\
\hline $55,60,65$ & $\begin{array}{l}\text { Minced } \\
\text { chicken }\end{array}$ & $\begin{array}{l}\text { Extraintestinal } \\
\text { pathogenic E. coli } \\
\text { (ExPEC) }\end{array}$ & No & $\begin{array}{l}\text { Aminoglycosides, } \\
\text { macrolides, } \\
\text { sulfonamides, } \\
\text { trimethoprim, tetracycline, } \\
\text { beta-lactams, cefotaxime, } \\
\text { phenicol, } \\
\text { aminoglycosides, } \\
\text { streptomycin } \\
\text { Depending on serotype } \\
\text { or strain }\end{array}$ & 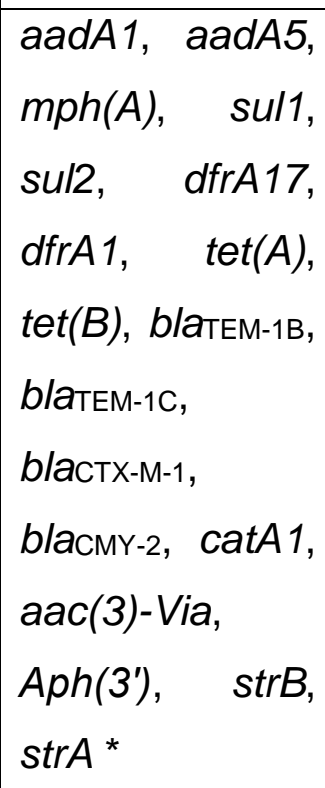 & Xu et al. (2019) \\
\hline 85,95 & $\begin{array}{l}\mathrm{BHI} \\
\text { medium }\end{array}$ & $\begin{array}{l}\text { MRSA } \\
\text { S. aureus (ATCC } \\
29737 \text {, control) }\end{array}$ & Yes & $\begin{array}{l}\text { Cefoxitin, cefadroxil, } \\
\text { cephalothin, colistin, } \\
\text { polymyxin, } \\
\text { aminoglycosides, } \\
\text { streptomycin, amikacin, } \\
\text { kanamycin:cyclic }\end{array}$ & $m e c A$ & Yehia et al. (2020) \\
\hline
\end{tabular}




\begin{tabular}{|l|l|l|l|l|l|l|}
\hline $\begin{array}{l}\text { Evaluation } \\
\text { temperature } \\
\left({ }^{\circ} \mathbf{C}\right)\end{array}$ & Medium & $\begin{array}{l}\text { Species and } \\
\text { strains }\end{array}$ & $\begin{array}{l}\text { Enhanced } \\
\text { thermal } \\
\text { resistance }\end{array}$ & $\begin{array}{l}\text { Stated antimicrobial } \\
\text { resistance profiles } \\
\text { (antimicrobial or class) }\end{array}$ & $\begin{array}{l}\text { Antimicrobial } \\
\text { Resistance } \\
\text { Genes } \\
\text { (ARGs) }\end{array}$ & $\begin{array}{l}\text { Reference } \\
\text { present }\end{array}$ \\
\hline & & & $\begin{array}{l}\text { peptides, bacitracin, } \\
\text { tetracycline: sulfonamide, } \\
\text { sulfamethoxazole, } \\
\text { nalidixic } \\
\text { acid:fluoroquinolone, } \\
\text { ciprofloxacin:oxazolidone, } \\
\text { linezolid:macrobid }\end{array}$ & \\
\hline
\end{tabular}

Table abbreviations: ARGs, antimicrobial resistance gene; AMR, Antimicrobial resistance; NS = Not stated 


\subsection{Is there evidence that ARGs can transfer from heat-treated}

AMR bacteria to other bacteria?

Very few publications were identified in the literature search that have directly addressed the fate of ARGs in heat-treated foods. Only four relevant publications were identified ( 
Table 2). Of these only one (Koncan et al., 2007) specifically looked at the fate of ARGs in conventionally cooked food in an in vitro mimic of cooking processes. Of the other publications; one in vitro mimic of commercial milk pasteurisation (Taher et al., 2020a); another was in vitro and not designed to mimic any particular heat treatment but did use strains originating from animal sources and temperatures and time similar to thermal processes used to treat and cook food (Le Devendec et al., 2018). A further publication that was considered relevant, but not applied to food, was an in vitro mimic of autoclaving (Masters et al., 1998). 
Table 2. Summary of the four studies identified by the literature search that address the impact of heat on the transfer of Antimicrobial Resistance Genes (ARGs)

\begin{tabular}{|c|c|c|c|c|}
\hline Publication & Koncan et al., 2007 & $\begin{array}{l}\text { Le Devendec et al., } \\
2018\end{array}$ & Taher et al., 2020a & Masters et al., 1998 \\
\hline Mimic & Cooking & General heat treatments & $\begin{array}{l}\text { Milk pasteurisation } \\
\text { (sterilisation) }\end{array}$ & Non-food autoclaving \\
\hline $\begin{array}{l}\text { Evaluation } \\
\text { temperatures } \\
\left({ }^{\circ} \mathrm{C}\right)\end{array}$ & NS & $\begin{array}{l}40,50,60,70,80,90, \\
100\end{array}$ & $63.5,121$ & 121,135 \\
\hline Species & E. faecalis & E. coli & S. aureus, S. sciuri & Plasmid (pUC18) \\
\hline $\begin{array}{l}\text { Antimicrobial } \\
\text { Resistance } \\
\text { Genes (ARGs) } \\
\text { present }\end{array}$ & $\operatorname{aac}\left(6^{\prime}\right)-l e-a p h\left(2^{\prime \prime}\right)-l a$ & $\begin{array}{l}\text { blacтх-м-1, blaсму-2, tetA, } \\
\text { strA }\end{array}$ & blaZ, mecC, tetK & NS \\
\hline $\begin{array}{l}\text { Stated } \\
\text { antimicrobial } \\
\text { resistance } \\
\text { profiles }\end{array}$ & $\begin{array}{l}\text { Aminoglycosides, } \\
\text { except to streptomycin } \\
\text { (Predicted profile, not } \\
\text { tested) }\end{array}$ & $\begin{array}{l}\text { Cephalosporins, } \\
\text { tetracycline, } \\
\text { streptomycin }\end{array}$ & $\begin{array}{l}\text { Penicillin, methicillin, } \\
\text { tetracycline }\end{array}$ & Ampicillin \\
\hline
\end{tabular}




\begin{tabular}{|l|l|l|l|l|}
\hline Publication & Koncan et al., 2007 & $\begin{array}{l}\text { Le Devendec et al., } \\
\mathbf{2 0 1 8}\end{array}$ & Taher et al., 2020a & Masters et al., 1998 \\
\hline $\begin{array}{l}\text { Recipient } \\
\text { species }\end{array}$ & E. faecalis & E. coli & S. aureus & E. coli \\
\hline $\begin{array}{l}\text { Transformation } \\
\text { demonstrated }\end{array}$ & NO & YES & YES & YES \\
\hline
\end{tabular}

Table abbreviations: ARGs, antimicrobial resistance gene; AMR, Antimicrobial resistance; NS, Not stated. 
Koncan et al. (2007) evaluated the possibility of detecting the aac(6')-aph(2') modifying aminoglycoside resistance gene in meat (chicken, pork, and beef) after conventional cooking procedures. This gene is reported to be encoded by plasmids and transposons, to be widely spread in Enterococcus faecalis, and confers resistance to most available aminoglycosides, except to streptomycin (Sparo et al., 2018). There are no details reported in the study as to whether the gene was on a plasmid in the $E$. faecalis studied.

Samples (25 g samples cut in the same shape, no dimensions given) of chicken, pork, and beef were inoculated with different dilutions $\left(10^{9}\right.$ to $\left.10^{3}\right)$ of $E$. faecalis (Delaware strain), carrying the bi-functional gene aac(6')-le-aph(2')-la. The samples were either boiled (20 $\mathrm{min}$ ), grilled on a cooking plate (10 $\mathrm{min}$ ), microwaved (5 min, $900 \mathrm{~W}$ ), or autoclaved for 20 minutes at 1 atmosphere and $121^{\circ} \mathrm{C}$. No details of the number of replicates, whether temperatures were recorded, and what end point temperatures were achieved are provided. After the heat treatments no bacteria were detected but positive polymerase chain reaction $(\mathrm{PCR})$ results for the bifunctional gene were observed in all samples. A direct correlation between the density of bacterial inoculum and the intensity of amplified DNA was also observed. Differences between medium were also found, with higher amounts of the bifunctional gene recovered in the beef samples, than in the pork or chicken. Transformation experiments to recipient $E$. faecalis $\mathrm{JH} 2-2$ with total DNA from samples were negative in all cases.

This study (Koncan et al., 2007), having been presented as a poster, is unfortunately lacking in detail. Though, it is the only study that has been identified that has addressed the fate of ARGs in conventionally cooked food. This study does suggest that heat treatments that are capable of destroying bacteria may not fully destroy ARGs. It also suggests that the survival of ARGs in foods subjected to the same heat treatment is different in different food matrices (which may be expected as the type of food matrix is known to contribute to the heat resistance of bacteria, as reported by Lewis et al. (2006) and de Jonge (2019) amongst others; it is likely that 
this is due to differences in the thermophysical and structural properties of different foods). This study did not provide any evidence that the bifunctional gene that was detected following heat treatment was a functional gene. DNA remaining after heat treatment is likely to be highly fragmented. A PCR test will still detect highly fragmented DNA remaining after heat treatment and produce a PCR positive amplicon. That the study was unable to transfer genes to a competent recipient strain may indicate that the genes were indeed not functional.

In our opinion, sequencing this gene would have provided a greater understanding the fragmentation, completeness, and structure of the gene. An alternative method of establishing whether the DNA was functional may have been to investigate the physical properties of the gene for authenticity and/or to clone the DNA into a plasmid vector and sequence this.

Le Devendec et al. (2018) evaluated the impact of heat treatment, using a traditional water bath method, on the possibility of ARGs being transferred from extended spectrum beta-lactamase (ESBL) E. coli. Five strains (2, 40, 174, and 241 details of which can be found in Chauvin et al. (2013); and 05-M63-1 details of which can be found in Fleury et al., 2015) were used that had previously been shown to carry either a blacтх-м-1 or a blaсмү-2 gene, which encode resistance to cephalosporins, on a plasmid ( $I n C / 1)$ and also carried tet $A$ and strA genes, which encode resistance to tetracycline and streptomycin. Suspensions in saline were subjected in a water bath to temperatures of $40,50,60,70,80,90$ or $100^{\circ} \mathrm{C}$ for $5,10,20,30$, or $60 \mathrm{~min}$.

Heat treatments at 40 and $50^{\circ} \mathrm{C}$ (for $5,10,20,30$, and 60 minutes) had little effect on bacterial numbers whereas at $60^{\circ} \mathrm{C}$ and above reduced bacterial numbers. Treatment at $60^{\circ} \mathrm{C}$ for $20 \mathrm{~min}$ and longer reduced bacterial numbers to below the limit of detection $\left(20 \mathrm{CFU} \mathrm{mL} \mathrm{L}^{-1}\right)$. All treatments at $70^{\circ} \mathrm{C}$ and above reduced bacterial numbers below the limit of detection $\left(20 \mathrm{CFU} \mathrm{mL}{ }^{-1}\right)$. All the tested colonies obtained from the suspensions heated to the highest temperatures for the longest time were, after treatment, found by PCR to yield the E. coli amplicon and included the amplicons of the blactх-м, blaсмч-2, tetA or strA ARGs initially present in the strains. 
The authors therefore concluded that heat stress did not appear to result in the loss of either the ARGs or plasmids.

The authors theorised that AMR E. coli that survived a moderate heat treatment were capable of transferring their ARGs to other bacteria present. To evaluate this risk, they sought conjugative plasmids in representative heat-treated suspensions (suspensions heated to $60^{\circ} \mathrm{C}$ for $10 \mathrm{~min}$ and longer in which few culturable bacteria could be detected). These suspensions were mixed with a rifampicin- and kanamycin-resistant recipient strain of E. coli K-12 CV601gfp. It is not clear from the publication at what temperature this test was carried out at, but it was carried out after the temperature treatment, implying that the conjugation experiments were at a different (lower) testing temperature. No conjugation could be observed in any of the nine heated suspensions. Suspensions heated to between $40^{\circ} \mathrm{C}$ and $70^{\circ} \mathrm{C}$ for $1 \mathrm{~h}$ were also tested by PCR assays, and all were positive for ARGs. We note that although detectable by PCR, beyond the conjugation test, no other test of gene functionality was carried out, or sequencing to examine fragmentation, completeness, and structure of the gene.

Further trials were carried out to assess whether ARGs from heated suspensions could be transferred to a recipient E. coli $\mathrm{DH} 5 \alpha$ strain by transformation. Three transformation assays were carried out.

In the first trial, suspensions from which no bacteria could be isolated (i.e., strains 2 and 40 , heated to $70^{\circ} \mathrm{C}$ for $30 \mathrm{~min}$; strain 174 , heated to $80^{\circ} \mathrm{C}$ for $30 \mathrm{~min}$; and strains 241 and $\mathrm{M} 63$, heated to $90{ }^{\circ} \mathrm{C}$ for $10 \mathrm{~min}$ ) were used. No transformant colonies could be detected after plating, indicating to the authors that the heattreated bacteria had been inactivated, though they could not exclude the possibility that a few viable cells were present. While the plasmid extracts were positive for the different expected genes, transformation assays yielded colonies from only from one strain (strain 2). The resulting colonies shared the phylogenetic group $(A)$ and PFGE profile of the recipient $\mathrm{DH} 5 \mathrm{a}$ strain and were found to have acquired one of the 
ARGs, tetA, from the heat-treated bacteria. They also contained Incl1 and IncF plasmids like the $E$. coli strain 2, suggesting that transformation had taken place.

In the second trial, cell lysates after heat treatment for strains 2 and 40 contained 5.76 and $1.85 \mathrm{ng} \mathrm{\mu L}^{-1}$ of plasmid DNA, respectively, and 0.86 and $1.76 \mathrm{ng} \mathrm{\mu L}^{-1}$ of total DNA, respectively, thus confirming the cellular lysates contained ARGs detectable by PCR. After electroporation with plasmid or total DNA, no transformant colonies could be obtained on the different supplemented media.

In the third assay, DNA concentration of the plasmid preparations ranged from 7 to $14 \mathrm{ng} \mathrm{\mu L}^{-1}$ and the concentrations for total DNA from 2.5 to $4.0 \mathrm{ng} \mathrm{\mu L}^{-1}$. After electroporation, colonies were obtained only from the transformation performed with one of the five ESBL E. coli strains (05-M63-1) on cefotaxime-supplemented media. The colonies were tested and found to belong to the phylogenetic group of the recipient strain, but were found to contained only the Incl1 plasmid, whereas the donor strain contained plasmids I1, FIB, FIC, and F. The colonies contained the blacтх-м-1 and sul 2 genes, but not the tet $A$ gene. These results suggest that recipient bacteria had acquired several ARGs, borne by an Incl1 plasmid, from bacteria that had been subjected to a heat treatment, $70^{\circ} \mathrm{C}$ for $30 \mathrm{~min}$, that would be considered effective in eliminating bacterial contamination in foods.

This somewhat limited study provides evidence that transformation from 'heatinactivated bacteria' is possible, although only a limited number of positive results were obtained, indicating that its occurrence is probably rare. Furthermore, as pointed out by the authors, the original suspensions contained more than $10^{6} \mathrm{CFU}$. Thus, indicating that a great number of AMR bacteria may need to be present as contaminants for sufficient ARGs to persist after heat treatment in order for any transfer to other bacteria to take place.

In their study, Le Devendec et al. (2018) concluded that the heat-treated bacteria had been inactivated since transformant colonies could be detected after plating. 
Though the authors highlighted that they could not exclude the possibility that suspensions still contained a few viable cells. We would suggest that another possibility was that heat treated bacteria could have been in a viable but nonculturable (VBNC) state. Taher et al.'s (2020a) study, as discussed below, suggests that AMR bacteria in a VBNC state are metabolically active and able to transcribe and translate genes.

Taher et al. (2020a) reported that a standard milk pasteurisation treatment $\left(63.5^{\circ} \mathrm{C}\right.$ for $30 \mathrm{~min}$ ) was not sufficient to inactivate plasmid-mediated ARGs blaZ, mecC and tetK, conferring resistance to beta-lactams, methicillin, and tetracyclines, respectively, of staphylococci (S. aureus and S. sciuri) and, in addition, would induce a VBNC state in these bacteria. In this study, milk and elution buffer were spiked at levels of $10^{5}$ and $10^{6}$ organisms, pasteurised $\left(63.5^{\circ} \mathrm{C}\right.$ for $\left.30 \mathrm{~min}\right)$ or sterilized $\left(121^{\circ} \mathrm{C}\right.$ for $15 \mathrm{~min}$ ), and then stored for up to 21 days at $4^{\circ} \mathrm{C}$. Copy numbers of the genes were quantified through PCR and qPCR after the heat treatments and during storage. Copy numbers of blaZ, and tetK genes remained similar after pasteurisation. While numbers of the mecC genes were lower after treatment. However, all genes increased in numbers over the 21-day storage time. Cultivability tests were negative, however use of the BacLight LIVE/DEAD stain showed a significant number of 'live' (green fluorescent) microorganisms in the pasteurised samples, qPCR of $16 \mathrm{~S}$ ribosomal DNA was also used to quantify VBNC. To assess whether the tested genes were still active, expressed and if resistance was still transferable to another microorganism, detection of the transmissibility of the tested genes was conducted in vitro using the electro-competent S. aureus RN42200 strain. The recipient cells showed resistance to methicillin and tetracycline after transformation using electroporation, thus indicating that both mecC and tetK genes were still functional and expressed.

Overall, this study (Taher et al., 2020a) provides some evidence that AMR bacteria may persist in a VBNC state in heat-treated foods and that ARGs from these heattreated bacteria may be still expressed and transferable. A focused literature search for evidence of any other publications on VBNC of AMR bacteria and heat 
treatments did not identify any other similar publications that ARGs may still be expressed by VBNC AMR bacteria. Though, as noted by Taher et al. (2020a), the occurrence of gene expression by VBNC bacteria after milk pasteurisation has also been reported by Gunasekera et al. (2002). Gunasekera et al. (2002) used E. coli and $P$. putida marked with the Green Fluorescent Protein (GFP) gene. They reported that a substantial portion of the GFP-marked E. coli and P. putida, inoculated in UHT milk, were rendered incapable of forming colonies by a heat treatment but were metabolically active after heat treatment. The heat treatment was $63.5^{\circ} \mathrm{C}$ for $30 \mathrm{~min}$, the same treatment that Taher et al. (2020a) used. The heat treatment reduced CFUs of both $E$. coli and $P$. putida by $>4 \log _{10} \mathrm{CFU} \mathrm{mL}^{-1}$, but GFP-based counts measured by epifluorescence microscopy were reduced by only $<2.5 \log _{10} \mathrm{CFU} \mathrm{mL}^{-1}$ for both of the organisms. While demonstrating that heattreated bacteria may be rendered incapable of forming colonies whilst remaining metabolically active this study does not provide any evidence on whether viable ARGs may be expressed or transfer to other bacteria from heat-treated bacteria.

A further study by Taher et al. (2020b) surveyed the prevalence of ARGs in commercially produced Australian milk. One hundred milk samples at farm level and 152 commercial milk samples (pasteurised and UHT milk) were surveyed, and samples tested by PCR. Their results showed that sul2, which encodes sulfonamide resistance, was the most prevalent plasmid-mediated gene in pasteurized and UHT milks ( $68 \%$ and $43 \%$, respectively). In contrast, mecA, which encodes for methicillin resistance, was not detected in any sample. Other plasmid-mediated ARGs, tetA (54.8 and $27.9 \%$ ), tetM (31 and 26.5\%), and blaтем-1в (42.9 and 32.4\%), were detected in pasteurized and UHT milks, respectively. Whether these ARGs were functional and could be transferred to recipient cells was not tested. The authors report that examination of cultures of pasteurised and UHT milk samples with light microscopy screening, the BacLight LIVE/DEAD assay, and scanning electron microscopy indicated that some of the bacteria may have lost their culturability but remained viable, i.e., were in a VBNC state. But the authors stated that further studies to identify, differentiate, and quantify those microorganisms. 
The only other publication identified as partially relevant but which was not applied to food, was a study by Masters et al. (1998) that demonstrated that a small laboratory constructed plasmid (pUC18) heated in distilled water at $121^{\circ} \mathrm{C}$ for $15 \mathrm{~min}$ in the presence of $0.5-2.0 \mathrm{ml} \mathrm{L}^{-1}$ sodium chloride was still capable of transforming ampicillin resistance to $E$. coli $(\mathrm{DH} 5 \mathrm{a})$ by electroporation. No transformable activity was detected when a plasmid preparation was autoclaved at $135^{\circ} \mathrm{C}$ for $20 \mathrm{~min}$. No further studies appear to have been undertaken on this subject by the researchers. The implications of these findings in relation to the persistence of functional ARGs in heat-treated foods do not appear to have been further studied by other researchers and this publication has not been cited by any other publication on this specific topic (i.e., heat resistance of ARGs). It is difficult to assess whether similar results would apply in more complex food matrices. However, many cooked foods contain sodium chloride, and receive a far less severe heat treatment, thus this study provides some limited supportive evidence that functional ARGs in plasmids could persist in foods after heat treatments.

It must be noted that all four studies used electroporation to assess transformability. While Le Devendec et al. (2018) considered that while the possibility of ARGs being transferred from heat-inactivated via natural transformation during food preparation could not be excluded it was likely to be infrequent. Only two of the studies used food matrices (Koncan et al., 2007; Taher et al., 2020a), the other two (Le Devendec et al., 2018; Masters et al., 1998) used simple saline matrices. As Le Devendec et al. (2018) admit, it is highly likely that the heat resistance of bacteria and ARGs in complex media or food matrices will differ from that in simple matrices.

None of the four studies identified addressed whether these genes can be acquired by gut microbiota. Though Le Devendec et al. (2018) considered that the probability of functional ARGs reaching the lower intestinal tract was low as was the chance of natural transformation in the gut. Reviews of the transfer of ARGs and exchange in the gut have been carried out (Schjørring \& Krogfelt, 2011; Broaders et al., 2013; Huddleston, 2014; Lerner et al., 2017) but whether ARGs from heat-treated foods can be a source of transfer is not discussed in these reviews nor has the literature 
search identified any publication that provide evidence that ARGs from heat-treated foods can be a source of transfer.

\subsection{Is there compelling evidence to show that heat completely destroys DNA (particularly ARGs either as non-cellular DNA or within AMR bacteria)?}

Heat will denature, degrade, and fragment DNA. It is fully accepted that heat treatments such as sterilization, UHT treatment, and pasteurization under welldefined time/temperature combinations will eradicate/kill vegetative bacterial cells and other microorganisms, including AMR bacteria. That in part is due to damage to their DNA, though no single event is responsible for cell death (Russell, 2003).

As previously discussed, a small number of publications have been identified that have addressed the survival of functional ARG after heat treatments. Three of the four publications identified show there is some evidence that some heat treatments will not completely destroy ARGs either as non-cellular DNA or within AMR bacteria. There is also some evidence that heat treatments may induce a VBNC state in AMR bacteria and they may continue to express ARGs after what may appear to be an effective heat treatment (Taher et al., 2020a).

There is evidence that bacterial DNA is not denatured by some heat treatments that would be expected to be sufficient to kill bacteria. Wang et al. (2014) reported that fragments of bacterial DNA (part of the eaeA gene of E. coli $0157: \mathrm{H} 7$ ) were not denatured when heated at $95^{\circ} \mathrm{C}$ for up to 30 minutes, as determined by measuring the absorbance of DNA at $260 \mathrm{~nm}$ after heat treatment. Ducey et al. (2017) also report that microbially-derived DNA (on cubes of beef bone and tissue) was still capable of being amplified by PCR when treated at $100^{\circ} \mathrm{C}$ for up to 240 minutes. Treatments of $150^{\circ} \mathrm{C}$ and $200^{\circ} \mathrm{C}$ were sufficient at eliminating microbial DNA. Examination of the thermal denaturation of bacterial cells by differential scanning 
calorimetry (DSC) has shown that higher temperatures are needed to denature DNA than kill bacterial cells (Mackey et al., 1991; Mohácsi-Farkas et al., 1999).

These studies did not study the functionality of the DNA. As previously noted, while there is evidence that ARGs can be detected using PCR after heat treatments, PCR detection does not prove that such genes are functional, either because the DNA integrity has been breached or regulatory proteins have coagulated.

As previously discussed in the introduction, Kharazmi et al. (2003) provides some evidence that although heat treatment does degrade lysed extracellular free DNA, surviving fragments may still be still of sufficient integrity to be transformed by other bacteria.

In conclusion, while there is compelling evidence to show that heat is capable of completely destroying microbial DNA (including ARGs), there is evidence that DNA may not fully denatured by some heat treatments that would be expected to be sufficient to kill bacteria and even if fragmented may remain functional.

\subsection{Can ARGs be up taken by surrounding viable bacteria present in other settings, including the human gut?}

It is recognised that ARGs can be transferred to other viable bacteria through transformation mechanisms. While dead cells cannot pass ARGs to other bacteria by cell-to-cell mechanisms such as conjugation or transduction (Verraes et al., 2013), as soon as DNA fragments have been released, ARGs may, theoretically, be transferred by transformation (McMahon et al., 2007; Verraes et al., 2013; Le Devendec et al., 2018; Pérez-Rodríguez \& Taban, 2019). The present understanding is that the process of transformation occurs with low frequency and is subject to a large number of requirements mostly observed in very controlled laboratory conditions (Verraes et al., 2013). 
Theoretically ARGs that are not destroyed during heat treatment and passing through stomach acid may be capable of transfer to other microbiota in the human gut and be incorporated, thereby becoming a functional source of AMR.

There is some literature (Aubry-Damon et al., 2004; Hart et al., 2006; Ramchandani et al., 2005) that lends weight to this hypothesis, although the literature search identified no evidence of ARGs from heat-treated or cooked food being shown to transfer to other microbiota in the human gut.

It is clear, as highlighted by other studies (Buffie \& Pamer, 2013; Taher et al., 2020a), that the capacity for the acquisition of ARGs by gut microbiota deserves more intensive study. In addition to the human gut environment, some literature exists to indicate that the food environment could potentially facilitate uptake of DNA by certain bacteria (Hasegawa et al., 2018).

As previously noted, while Le Devendec et al. (2018) could not completely exclude the possibility of the transfer of ARGs from heat-inactivated $E$. coli via natural transformation during food preparation, they considered that given the "infrequency of natural transformation and low probability of a whole functional resistance gene reaching the lower intestinal tract", they believed it unlikely for indigenous Enterobacteriaceae from the digestive microbiota to be transformed by DNA from heat-inactivated foodborne bacteria.

\subsection{What is the impact of different heat treatments on ARG uptake by viable bacteria?}

Few publications appear to have directly addressed the impact of different heat treatments on ARG uptake by viable bacteria. Different cooking treatments were compared by Koncan et al. (2007), but this study was limited, no time-temperatures were provided, and transformation experiments to recipient $E$. faecalis $\mathrm{JH} 2-2$ with 
total DNA from samples (irrespective of type of heat treatment) were negative in all cases.

Different heat treatments are highly likely to have an impact on the survival and viability ARGs, whether as cell free DNA or in mobile elements such as phage/GTAs or MVs. It is likely that the most important factors will be the maximum temperature the gene is subjected to, the duration at this temperature and temperature history (come-up and come-down times), and the type of food matrix.

\subsection{Is there any evidence of uptake of heat damaged DNA, and particularly ARGs, by pathogenic and non-pathogenic bacteria?}

Kharazmi et al. (2003) found that although heat treatment does degrade lysed cell free ARGs, surviving fragments may still be of sufficient integrity to be transformed by other bacteria. As previously discussed, four publications have directly addressed the uptake of ARGs to viable bacteria from "heat-treated" bacteria. Of these, one (Koncan et al., 2007) did not show that transformation was possible from heat-treated AMR bacteria. In contrast, the other publications (Le Devendec et al., 2018; Taher et al., 2020a; Masters et al., 1998) provide some evidence that the transformation of ARGs from heat-treated bacteria is possible under laboratory conditions. None of these publications examined the degree of fragmentation of any surviving ARGs on functionality.

\subsection{Is there any evidence to suggest that the behaviour of chromosomal DNA and plasmid DNA in response to heat differs?}

No publications were identified that have directly compared the behaviour of chromosomal DNA and plasmid DNA in response to heat. 
The four studies on the potential impact of heat treatments on ARGs that were identified, and reviewed, appear to have considered their survival in plasmidmediated DNA. Though the resistances could be both plasmid and chromosomal. While one of the four studies (Koncan et al., 2007) did not specifically mention plasmids, the gene they investigated, aac(6')-le-aph(2')-la, is reported to be encoded by plasmids and transposons.

\subsection{Is there any evidence to suggest that ARGs can transfer via heat-tolerant phages/GTAs?}

Phages/GTAs have been identified as a potentially important vectors in the transfer of ARGs. In theory ARGs could remain protected in thermally tolerant phages/GTAs that survive heat treatments that are effective in killing bacteria. There is clear evidence of the persistence of thermally-tolerant phages in heat-treated foods (Sommer et al., 2019). As quoted in the introduction of this review, Jebri et al. (2020) theorised that phages surviving processing methods could be a reservoir of ARGs in RTE food.

No studies appear to have addressed the impact of heat treatments of food on the survival and transfer of ARGs via phages/GTAs. The mechanisms responsible for phage/GTA transfer of ARGs and their importance and role in the transfer of ARGs do not yet appear to have been fully explored. There appears to be no evidence of whether this is more than a theoretical risk.

\subsection{Is there any evidence on the role of membrane vesicles (MVs) in the survival and transfer of ARGs from AMR bacteria subjected to heat treatments?}

It is not clear from the literature whether MVs containing ARGs are any more heat tolerant than the bacteria from which they come. The literature search did not 
identify any studies that have addressed the impact of heat treatments of food on the survival and transfer of ARGs via MVs.

Lee et al. (2013) reported that heat-treated MVs from S. aureus (ATCC 14458) containing BlaZ, a $\beta$-lactamase protein, did not mediate the survival of ampicillinsusceptible bacteria. Their study did not find BlaZ genes in MVs from S. aureus but did identify MVs containing the Beta-lactamase protein. They found that non-heattreated MVs containing this protein did enable other ampicillin-susceptible Gramnegative and Gram-positive bacteria to survive in the presence of ampicillin. But MVs that contained this protein that were first heated to $100^{\circ} \mathrm{C}$ for $20 \mathrm{~min}$ did not mediate the survival of ampicillin-susceptible bacteria in the presence of ampicillin. This provides some evidence that high temperature heat treatments may inactivate ARGs in MVs. However, the heat treatment used was at a relatively high temperature and long time in comparison to heat treatments that are equivalent to $70^{\circ} \mathrm{C}$ for at least $2 \mathrm{~min}$, and the MVs were in a simple saline matrix rather than a complex food matrix. 


\section{Conclusions and recommendations for further work}

Overall, this review has established that there is very limited evidence whether different heat treatments applied to eliminate bacterial contamination in foods also induces sufficient damage to ARGs to prevent or inhibit their uptake by surrounding viable bacteria present in other settings, including the human gut and other foods.

The literature review showed that there is evidence that AMR bacteria are likely to be no more heat-resistant than non-AMR bacteria. It is therefore apparent that heat treatments sufficient to kill non-AMR bacteria (such as $70^{\circ} \mathrm{C}$ for at least $2 \mathrm{~min}$, or the equivalent) will be equally effective in killing AMR bacteria.

The literature suggests that, theoretically, functional ARGs could potentially survive in heat-treated food either as (1) cell free DNA lysed from heat-treated AMR bacterial cells, (2) within heat-tolerant phage/GTAs, (3) within MVs, (4) within VBNC heat-treated AMR bacterial cells. These genes could subsequently theoretically be transferred to live bacteria through a range of HGT mechanisms.

What limited practical evidence exists does imply that heat treatments that are effective at eliminating bacteria may not be sufficient to destroy ARGs and that it is possible in the laboratory to transfer those genes to other bacteria. We caution that some of the evidence of survival of ARGs after heat treatment is limited to positive results based only on PCR and not supported by culture, and which therefore do not provide proof of gene expression or functionality.

It is clear that there are insufficient numbers of published studies on this subject to undertake any reliable analysis of the data or draw meaningful conclusions regarding the evidence on the impact of different heat treatments on ARG uptake by viable bacteria and a clear knowledge gap. 
- We would recommend further focused practical research be undertaken to assess the survival of functional ARGs in food matrices that have undergone heat treatment and whether they can be transferred to other bacteria in other matrices, to provide evidence for a full assessment of risk in relation to the transfer of ARGs from heat-treated foods to bacteria in other matrices.

It is clear that any future work should carefully consider the development and adoption of standardised testing protocols to ensure the value of future research and that results can be compared and analysed against similar studies. Although limited in scope, further studies initially based on the approach and protocols of Le Devendec et al. (2018) would enable a direct comparison of results to be made.

Since there is evidence that microbial resistance to heat in different matrices and subject to different (non-isothermal) time/temperature profiles differs, it is important that suitable food matrices and representative time/temperature treatments should be considered in such studies.

There is a theoretical risk that heat tolerant phages/GTAs and MVs may be a reservoir and vector for ARGs in heat-treated foods, there would appear to be no published evidence that has addressed this and hence a gap in the knowledge on their significance.

- We would recommend that there is a need to support appropriate practical studies on the transmission of ARGs by phages/GTAs and MVs, the impact of heat treatments on the survival of ARG carrying phage/GTAs and MVs, and the possible transfer of ARGs between bacteria via these mechanisms.

No evidence has been found that ARGs from heat-treated food may transfer to bacteria in the human gut after ingestion. There is some limited evidence that this potential exists but a gap in the knowledge on if this can occur in practice. 
- We would recommend that it would be prudent to support appropriate practical research studies on whether functional ARGs are able to survive the conditions that would be encountered in the human stomach, i.e., stomach acids, following ingestion and are able to transfer to other microbiota that may be found in the human gut.

Overall, this review has determined that there are gaps in the knowledge concerning the persistence of ARGs in heat-treated food. We hope that highlighting these gaps may focus future work on this topic, depending on the priorities and budgets of the relevant funding bodies. We would stress that it is essential in any further work that assumptions are not made regarding the temperature/time response during cooking/heating and that accurate relevant measurements are made to ensure that conditions truly mimic cooking / thermal processes.

Although not a focus of this review, there is clearly a concern that sub-lethal food processing heat treatments may play a role in an increase in AMR. There appears to be little evidence and a gap in the knowledge on the impact of sub-lethal heat treatments on AMR bacteria and genes. In our opinion, there is clearly a need to define lethal parameters and identify "sub-lethal heat treatments" that have been adopted by the industry, and what their impact may be on AMR bacteria and ARGs. In order to assess this, heat treatments need to be fully characterised, i.e., what endpoint temperatures and time/temperature histories would be expected in foods subject to different heat treatment.

- We would recommend the support of appropriate practical research studies to establish the impact of sub-lethal heat treatments on AMR bacteria and ARGs in food matrices to provide evidence for a full assessment of risk in relation to the survival of AMR bacteria and functional ARGs in sub-lethally heat-treated foods. 
Also, again while not a focus of this review, while there are many publications on the thermal inactivation of bacteria (particularly pathogens) during a wide variety of cooking operations, especially regarding the gridling of burgers (patties) and steaks, there appears to be gap in the literature specifically on the impact of different domestic or foodservice cooking methods on AMR bacteria (as well as ARGs).

- We would recommend the support of appropriate practical research studies to establish the impact of different domestic or foodservice cooking methods on AMR bacteria and ARGs in food matrices to provide evidence for a full assessment of risk in relation to the survival of AMR bacteria and functional ARGs in such cooked foods. 


\section{Acknowledgements}

The authors would like to thank those professionals who provided their time, assistance, data, and opinions for this project.

We would also like to thank the Food Standards Agency (FSA) for funding this study. 


\section{References}

Ahmadi, H., Radford, D., Kropinski, A. M., Lim, L. T., \& Balamurugan, S. (2017). Thermal-stability and reconstitution ability of Listeria phages $\mathrm{P} 100$ and A511. Frontiers in Microbiology, 8, 2375.

https://doi.org/10.3389/fmicb.2017.02375

Akhtar, M., Maserati, A., Diez-Gonzalez, F., \& Sampedro, F. (2016). Does antibiotic resistance influence shiga-toxigenic Escherichia coli $\mathrm{O} 26$ and $\mathrm{O} 103$ survival to stress environments? Food Control, 68, 330-336.

https://doi.org/10.1016/j.foodcont.2016.04.011

Anderson, S. A., Woo, R. Y., \& Crawford, L. M. (2001). Risk assessment of the impact on human health of resistant Campylobacter jejuni from fluoroquinolone use in beef cattle. Food Control, 12(1), 13-25.

https://doi.org/10.1016/s0956-7135(00)00014-1

Aubry-Damon, H., Grenet, K., Sall-Ndiaye, P., Che, D., Cordeiro, E., Bougnoux, M. E., Rigaud, E., Le Strat, Y., Lemanissier, V., Armand-Lefèvre, L., Delzescaux, D., Desenclos, J. C., Liénard, M., \& Andremont, A. (2004). Antimicrobial resistance in commensal flora of pig farmers. Emerging Infectious Diseases, 10, 873-879.

https://doi.org/10.3201/eid1005.030735

Bacon, R. T., Ransom, J. R., Sofos, J. N., Kendall, P. A., Belk, K. E., \& Smith, G. C. (2003). Thermal inactivation of susceptible and multiantimicrobial-resistant Salmonella strains grown in the absence or presence of glucose. Applied and Environmental Microbiology, 69(7), 4123-4128.

https://doi.org/10.1128/aem.69.7.4123-4128.2003 
Bengtsson-Palme, J. (2017). Antibiotic resistance in the food supply chain: where can sequencing and metagenomics aid risk assessment? Current Opinion in Food Science, 14, 66-71.

https://doi.org/10.1016/i.cofs.2017.01.010

Bennani, H., Mateus, A., Mays, N., Eastmure, E., Stärk, K. D., \& Häsler, B. (2020). Overview of evidence of antimicrobial use and antimicrobial resistance in the food chain. Antibiotics, 9(2), 49.

https://doi.org/10.3390/antibiotics9020049

Bennett, P. M. (2008). Plasmid encoded antibiotic resistance: acquisition and transfer of antibiotic resistance genes in bacteria. British Journal of Pharmacology, 153(S1) S347-S357.

https://doi.org/10.1038/sj.bjp.0707607

Bennett, P. M., Livesey, C. T., Nathwani, D., Reeves, D. S., Saunders, J. R., \& Wise, R. (2004). An assessment of the risks associated with the use of antibiotic resistance genes in genetically modified plants: report of the Working Party of the British Society for Antimicrobial Chemotherapy. Journal of Antimicrobial Chemotherapy, 53(3), 418-431.

https://doi.org/10.1093/jac/dkh087

Bertolatti, D., Munyard, S. J., Grubb, W. B., \& Binns, C. W. (2001). Thermal inactivation of antimicrobial-resistant Gram-positive cocci in chicken meat: D and Z value determinations. International Journal of Environmental Health Research, 11(3), 257-266.

https://doi.org/10.1080/09603120120070874 
Bitto, N. J., Chapman, R., Pidot, S., Costin, A., Lo, C., Choi, J., D’Cruze, T., Reynolds, E. C., Dashper, S. G., Turnbull, L., Whitchurch, C. B., Stinear, T. P., Stacey, K. J., \& Ferrero, R. L. (2017). Bacterial membrane vesicles transport their DNA cargo into host cells. Scientific Reports, 7(1), 1-11.

https://doi.org/10.1038/s41598-017-07288-4

Broaders, E., Gahan, C. G., \& Marchesi, J. R. (2013). Mobile genetic elements of the human gastrointestinal tract: potential for spread of antibiotic resistance genes. Gut Microbes, 4(4), 271-280.

https://doi.org/10.4161/gmic.24627

Buffie, C. G., \& Pamer, E. G. (2013). Microbiota-mediated colonization resistance against intestinal pathogens. Nature Reviews Immunology, 13(11), 790-801. https://doi.org/10.1038/nri3535

Campbell, J. A., Dickson, J. S., Cordray, J. C., Olson, D. G., Mendonca, A. F., \& Prusa, K. J. (2014). Survival of methicillin-resistant Staphylococcus aureus during thermal processing of frankfurters, summer sausage, and ham. Foodborne Pathogens and Disease, 11(1), 50-54.

https://doi.org/10.1089/fpd.2013.1571

Capita, R., \& Alonso-Calleja, C. (2013). Antibiotic-resistant bacteria: a challenge for the food industry. Critical Reviews in Food Science and Nutrition, 53(1), 11-48. https://doi.org/10.1080/10408398.2010.519837

Caruana, J. C., \& Walper, S. A. (2020). Bacterial membrane vesicles as mediators of microbe-microbe and microbe-host community interactions. Frontiers in Microbiology, 11, 432.

https://doi.org/10.3389/fmicb.2020.00432 
Chauvin, C., Le Devendec, L., Jouy, E., Le Cornec, M., Francart, S., Marois-Créhan, C., \& Kempf, I. (2013). National prevalence of resistance to third-generation cephalosporins in Escherichia coli isolates from layer flocks in France. Antimicrobial Agents and Chemotherapy, 57(12), 6351-6353.

https://doi.org/10.1128/aac.01460-13

Colavecchio, A., Cadieux, B., Lo, A., \& Goodridge, L. D. (2017). Bacteriophages contribute to the spread of antibiotic resistance genes among foodborne pathogens of the Enterobacteriaceae family-a review. Frontiers in Microbiology, 8, 1108.

https://doi.org/10.3389/fmicb.2017.01108

De Jonge, R. (2019). Predictable and unpredictable survival of foodborne pathogens during non-isothermal heating. International Journal of Food Microbiology, 291, 151160.

https://doi.org/10.1016/j.ijfoodmicro.2018.11.018

Doherty, A. M., McMahon, C. M. M., Sheridan, J. J., Blair, I. S., McDowell, D. A., \& Hegarty, T. (1998). Thermal resistance of Yersinia enterocolitica and Listeria monocytogenes in meat and potato substrates. Journal of Food Safety, 18(2), 6983.

https://doi.org/10.1111/j.1745-4565.1998.tb00204.x

Dombroski, C. S., Jaykus, L. A., Green, D. P., \& Farkas, B. E. (1999). Use of mutant strain for evaluating processing strategies to inactivate Vibrio vulnificus in oysters. Journal of Food Protection, 62, 592-600.

https://doi.org/10.4315/0362-028x-62.6.592 
Ducey, T. F., Collins, J. C., Ro, K. S., Woodbury, B. L., \& Griffin, D. D. (2017). Hydrothermal carbonization of livestock mortality for the reduction of pathogens and microbially-derived DNA. Frontiers of Environmental Science \& Engineering, 11(3), $1-8$.

https://doi.org/10.1007/s11783-017-0930-x

Duffy, G., Walsh, C., Blair, I. S., \& McDowell, D. A. (2006). Survival of antibiotic resistant and antibiotic sensitive strains of E. coli $\mathrm{O} 157$ and E. coli O26 in food matrices. International Journal of Food Microbiology, 109(3), 179-186.

https://doi.org/10.1016/j.ijfoodmicro.2006.01.024

Ferri, M., Ranucci, E., Romagnoli, P., \& Giaccone, V. (2017). Antimicrobial resistance: a global emerging threat to public health systems. Critical Reviews in Food Science and Nutrition, 57(13), 2857-2876.

https://doi.org/10.1080/10408398.2015.1077192

Fleury, M. A., Mourand, G., Jouy, E., Touzain, F., Le Devendec, L., De Boisseson, C., Eono, F., Cariolet, R., Guérin, A., Le Goff, O., Blanquet-Diot, S., Alric, M. \& Kempf, I. (2015). Impact of ceftiofur injection on gut microbiota and Escherichia coli resistance in pigs. Antimicrobial Agents and Chemotherapy, 59(9), 5171-5180. https://doi.org/10.1128/aac.00177-15

Foegeding, P. M. \& Stanley, N. W. (1991). Listeria innocua transformed with an antibiotic resistance plasmid as a thermal-resistance indicator for Listeria monocytogenes. Journal of Food Protection, 54, 519-523.

https://doi.org/10.4315/0362-028x-54.7.519 
Friedman, M. (2015). Antibiotic-resistant bacteria: prevalence in food and inactivation by food-compatible compounds and plant extracts. Journal of Agricultural and Food Chemistry, 63(15), 3805-3822.

https://doi.org/10.1021/acs.jafc. 5 b00778

Gómez-Gómez, C., Blanco-Picazo, P., Brown-Jaque, M., Quirós, P., RodríguezRubio, L., Cerdà-Cuellar, M., \& Muniesa, M. (2019). Infectious phage particles packaging antibiotic resistance genes found in meat products and chicken feces. Scientific Reports, 9(1), 1-11.

https://doi.org/10.1038/s41598-019-49898-0

Griffith, F. (1928). The significance of pneumococcal types. Epidemiology \& Infection, 27(2), 113-159.

Gunasekera, T. S., Sørensen, A., Attfield, P. V., Sørensen, S. J., \& Veal, D. A. (2002). Inducible gene expression by nonculturable bacteria in milk after pasteurization. Applied and Environmental Microbiology, 68(4), 1988-1993. https://doi.org/10.1128/aem.68.4.1988-1993.2002

Hall, J. P., Brockhurst, M. A., \& Harrison, E. (2017). Sampling the mobile gene pool: innovation via horizontal gene transfer in bacteria. Philosophical Transactions of the Royal Society B: Biological Sciences, 372(1735), 20160424.

https://doi.org/10.1098/rstb.2016.0424

Hart, W. S., Heuzenroeder, M. W., \& Barton, M. D. (2006). A study of the transfer of tetracycline resistance genes between Escherichia coli in the intestinal tract of a mouse and a chicken model. Journal of Veterinary Medicine. B, Infectious Diseases and Veterinary Public Health, 53, 333-340.

https://doi.org/10.1111/j.1439-0450.2006.00967.x 
Hasegawa, H., Suzuki, E., \& Maeda, S. (2018). Horizontal plasmid transfer by transformation in Escherichia coli: environmental factors and possible mechanisms. Frontiers in Microbiology, 9, 2365.

https://doi.org/10.3389/fmicb.2018.02365

Hu, X., Kang, F., Yang, B., Zhang, W., Qin, C., \& Gao, Y. (2019). Extracellular polymeric substances acting as a permeable barrier hinder the lateral transfer of antibiotic resistance genes. Frontiers in Microbiology, 10, 736.

https://doi.org/10.3389/fmicb.2019.00736

Huddleston, J. R. (2014). Horizontal gene transfer in the human gastrointestinal tract: potential spread of antibiotic resistance genes. Infection and Drug Resistance, 7, 167.

https://doi.org/10.2147/idr.s48820

Hughes, M. K., Yanamala, S., Francisco, M. S., Loneragan, G. H., Miller, M. F., \& Brashears, M. M. (2010). Reduction of multidrug-resistant and drug-susceptible Salmonella in ground beef and freshly harvested beef briskets after exposure to commonly used industry antimicrobial interventions. Journal of Food Protection, 73(7), 1231-1237.

https://doi.org/10.4315/0362-028x-73.7.1231

Hutchison, M. L., Corry, J. E. L., \& Madden, R. H (2020). A review of the impact of food processing on antimicrobial- resistant bacteria in secondary processed meats and meat products. FS301059. Food Standards Agency.

https://doi.org/10.46756/sci.fsa.bxn990 
Jebri, S., Rahmani, F., \& Hmaied, F. (2021). Bacteriophages as antibiotic resistance genes carriers in agro-food systems. Journal of Applied Microbiology, 130(3), 688698.

https://doi.org/10.1111/jam.14851

Jiang, X., Yu, T., Liu, L., Li, Y., Zhang, K., Wang, H. \& Shi, L. (2017). Examination of Quaternary Ammonium Compound resistance in Proteus mirabilis isolated from cooked meat products in China. Frontiers in Microbiology, 8, 2417.

https://doi.org/10.3389/fmicb.2017.02417

Jiang, X., Yu, T., Wu, N., Meng, H., \& Shi, L. (2014). Detection of qnr, aac(6 ')-lb-cr and qepA genes in Escherichia coli isolated from cooked meat products in Henan, China. International Journal of Food Microbiology, 187, $22-25$.

https://doi.org/10.1016/.ijfoodmicro.2014.06.026

Jung, Y. S., \& Beuchat, L. R. (1999). Survival of multidrug-resistant Salmonella typhimurium DT104 in egg powders as affected by water activity and temperature. International Journal of Food Microbiology, 49(1-2), 1-8.

https://doi.org/10.1016/s0168-1605(99)00013-6

Jung, Y. S., \& Beuchat, L. R. (2000). Sensitivity of multidrug-resistant Salmonella typhimurium DT104 to organic acids and thermal inactivation in liquid egg products. Food Microbiology, 17(1), 63-71.

https://doi.org/10.1006/fmic.1999.0287

Kharazmi, M., Bauer, T., Hammes, W. P., \& Hertel, C. (2003). Effect of food processing on the fate of DNA with regard to degradation and transformation capability in Bacillus subtilis. Systematic and Applied Microbiology, 26(4), 495-501. https://doi.org/10.1078/072320203770865774 
Komora, N., Bruschi, C., Rui, M., Ferreira, V., \& Teixeira, P. (2017). Survival of Listeria monocytogenes with different antibiotic resistance patterns to foodassociated stresses. International Journal of Food Microbiology, 245, 79-87. https://doi.org/10.1016/j.ijfoodmicro.2017.01.013

Koncan, R., García-Albiach, R., Bravo, D., Cantón, R., Baquero, F., Cornaglia, G., \& del Campo, R. (2007). The fate of antibiotic resistance genes in cooked meat. International Journal of Antimicrobial Agents, 29, S130-S130.

https://doi.org/10.1016/s0924-8579(07)70414-4

Kulas, M., Porto-Fett, A. C., Swartz, R. S., Shane, L. E., Strasser, H., Munson, M., Shoyer, B. A., \& Luchansky, J. B. (2015). Thermal inactivation of shiga toxinproducing Escherichia coli cells within veal cordon bleu. Journal of Food Safety, 35(3), 403-409.

https://doi.org/10.1111/jfs.12188

Kulkarni, H. M., Nagaraj, R., \& Jagannadham, M. V. (2015). Protective role of E. coli outer membrane vesicles against antibiotics. Microbiological Research, 181, 1-7. https://doi.org/10.1016/j.micres.2015.07.008

Le Devendec, L., Jouy, E., \& Kempf, I. (2018). Evaluation of resistance gene transfer from heat-treated Escherichia coli. International Journal of Food Microbiology, 270, $39-43$.

https://doi.org/10.1016/j.ijfoodmicro.2018.02.019

Lee, H., Ku, H. J., Lee, D. H., Kim, Y. T., Shin, H., Ryu, S., \& Lee, J. H. (2016).

Characterization and genomic study of the novel bacteriophage HY01 infecting both 
Escherichia coli O157: H7 and Shigella flexneri: potential as a biocontrol agent in food. PloS One, 11(12), e0168985.

https://doi.org/10.1371/journal.pone.0168985

Lee, J., Lee, E. Y., Kim, S. H., Kim, D. K., Park, K. S., Kim, K. P., Kim, Y. K., Roh, T. Y., \& Gho, Y. S. (2013). Staphylococcus aureus extracellular vesicles carry biologically active $\beta$-lactamase. Antimicrobial Agents and Chemotherapy, 57(6), 2589-2595.

https://doi.org/10.1128/aac.00522-12

Lerner, A., Matthias, T., \& Aminov, R. (2017). Potential effects of horizontal gene exchange in the human gut. Frontiers in Immunology, 8, 1630.

https://doi.org/10.3389/fimmu.2017.01630

Lewis, R. J., Baldwin, A., O'Neill, T., Alloush, H. A., Nelson, S. M., Dowman, T., \& Salisbury, V. (2006). Use of Salmonella enterica serovar Typhimurium DT104 expressing lux genes to assess, in real time and in situ, heat inactivation and recovery on a range of contaminated food surfaces. Journal of food engineering, 76(1), 41-48.

https://doi.org/10.1016/j.jfoodeng.2005.05.023

Li, L., Ye, L., Yu, L., Zhou, C., \& Meng, H. (2016). Characterization of extended spectrum beta-lactamase producing enterobacteria and methicillin-resistant Staphylococcus aureus isolated from raw pork and cooked pork products in South China. Journal of Food Science, 81, M1773-1777.

https://doi.org/10.1111/1750-3841.13346

Lianou, A., \& Koutsoumanis, K. P. (2013). Evaluation of the strain variability of Salmonella enterica acid and heat resistance. Food Microbiology, 34(2), 259-267. 
Liao, X., Ma, Y., Daliri, E. B. M., Koseki, S., Wei, S., Liu, D., Ye, X., Chen, S. \& Ding, T. (2020). Interplay of antibiotic resistance and food-associated stress tolerance in foodborne pathogens. Trends in Food Science \& Technology, 95, 97-106.

https://doi.org/10.1016/j.tifs.2019.11.006

Likotrafiti, E., Oniciuc, E. A., Prieto, M., Santos, J. A., López, S., \& Alvarez-Ordóñez, A. (2018). Risk assessment of antimicrobial resistance along the food chain through culture-independent methodologies. EFSA Journal, 16, e160811.

https://doi.org/10.2903/j.efsa.2018.e160811

Lorenz, M. G., \& Wackernagel, W. (1994). Bacterial gene transfer by natural genetic transformation in the environment. Microbiological Reviews, 58(3), 563-602.

https://doi.org/10.1128/mr.58.3.563-602.1994

Luchansky, J. B., Porto-Fett, A. C., Shoyer, B. A., Thippareddi, H., Amaya, J. R., \& Lemler, M. (2014). Thermal inactivation of Escherichia coli O157: H7 and non-O157 Shiga toxin-producing Escherichia coli cells in mechanically tenderized veal. Journal of Food Protection, 77(7), 1201-1206.

https://doi.org/10.4315/0362-028x.jfp-13-414

Ma, Y., Lan, G., Li, C., Cambaza, E. M., Liu, D., Ye, X., Chen, S. \& Ding, T. (2019). Stress tolerance of Staphylococcus aureus with different antibiotic resistance profiles. Microbial Pathogenesis, 133, 103549.

https://doi.org/10.1016/j.micpath.2019.103549 
Mackey, B. M., Miles, C. A., Parsons, S. E., \& Seymour, D. A. (1991). Thermal denaturation of whole cells and cell components of Escherichia coli examined by differential scanning calorimetry. Microbiology, 137(10), 2361-2374.

https://doi.org/10.1099/00221287-137-10-2361

Masters, C. I., Miles, C. A., \& Mackey, B. M. (1998). Survival and biological activity of heat damaged DNA. Letters in Applied Microbiology, 27(5), 279-282.

https://doi.org/10.1046/j.1472-765x.1998.00447.x

Mateus, A., Takahashi, E. A., Elkholly, D. A., Crotta, M., Ekiri, A., Wylie, C., Guinat, C., Patricio, M., Marshall, L., Ferreira, J. P., Stärk, K. \& Guitian, J. (2016). A systematic review to assess the significance of the food chain in the context of antimicrobial resistance (AMR) with particular reference to pork and poultry meat, dairy products, seafood and fresh produce on retail sale in the UK. FSA FS102127. Royal Veterinary College. Available online at:

https://www.food.gov.uk/research/foodborne-diseases/a-systematic-review-of-amrbacteria-in-pork-poultry-dairy-products-seafood-and-fresh-produce-at-uk-retail-level (Last accessed: May 2021)

McInnes, R. S., McCallum, G. E., Lamberte, L. E., \& van Schaik, W. (2020). Horizontal transfer of antibiotic resistance genes in the human gut microbiome. Current Opinion in Microbiology, 53, 35-43.

https://doi.org/10.1016/j.mib.2020.02.002

McKay, A. M. (2008). Antimicrobial resistance and heat sensitivity of oxacillinresistant, mecA-positive Staphylococcus spp. from unpasteurized milk. Journal of Food Protection, 71(1), 186-190.

https://doi.org/10.4315/0362-028x-71.1.186 
McMahon, M. A. S., Xu, J., Moore, J. E., Blair, I. S., \& McDowell, D. A. (2007).

Environmental stress and antibiotic resistance in food-related pathogens. Applied Environmental Microbiology, 73, 211-217.

https://doi.org/10.1128/aem.00578-06

Mohácsi-Farkas, C., Farkas, J., Meszaros, L., Reichart, O., \& Andrassy, E. (1999). Thermal denaturation of bacterial cells examined by differential scanning calorimetry. Journal of Thermal Analysis and Calorimetry, 57(2), 409-414.

https://doi.org/10.1023/a:1010139204401

Munita, J. M., \& Arias, C. A. (2016). Mechanisms of antibiotic resistance. Virulence Mechanisms of Bacterial Pathogens, 481-511.

https://doi.org/10.1128/9781555819286.ch17

Murphy, J., Mahony, J., Bonestroo, M., Nauta, A., \& van Sinderen, D. (2014). Impact of thermal and biocidal treatments on lactococcal 936-type phages. International Dairy Journal, 34(1), 56-61.

https://doi.org/10.1016/j.idairyj.2013.06.011

O'Neill, J. (2014). Antimicrobial Resistance: Tackling a crisis for the health and wealth of nations. Available online at: https://amr-review.org/ (Last accessed: May 2021).

Overballe-Petersen, S., Harms, K., Ludovic, A. A., Orlando , J., Moreno Mayar, V., Rasmussen, S., Dahld, T.W., Rosing, M. T., Poole, A. M., Sicheritz-Ponten, T., Brunak, S., Inselmann, S., de Vriesg, J., Wackernagel, W., Pybush, O. G., Nielsen, R., Johnsen, P. J. Nielsen, K. M., \& Willerslev, E. (2013). Bacterial natural transformation by highly fragmented and damaged DNA. PNAS, 110(49), 1986019865. 
Pérez-Rodríguez, F., \& Mercanoglu Taban, B. (2019). A state-of-art review on multidrug resistant pathogens in foods of animal origin: risk factors and mitigation strategies. Frontiers in Microbiology, 10, 2091.

https://doi.org/10.3389/fmicb.2019.02091

Food Standards Agency. (2016). Chief Scientific Adviser's Science Report, Issue four: Antimicrobial resistance in the food supply chain. Food Standards Agency. Available online at: https://www.food.gov.uk/sites/default/files/media/document/csaamr-report 0\%20\%281\%29.pdf (Last accessed: May 2021).

Ramchandani, M., Manges, A. R., DebRoy, C., Smith, S. P., Johnson, J.R., \& Riley, L. W. (2005). Possible animal origin of human-associated, multidrug-resistant, uropathogenic Escherichia coli. Clinical Infectious Diseases, 40, 251-257.

https://doi.org/10.1086/426819

Report of the Scientific Committee of the Food Safety Authority of Ireland (2015). Potential for Transmission of Antimicrobial Resistance in the Food Chain. Food Safety Authority of Ireland.

Rincón, A. M., \& Singh, R. K. (2016). Effect of radio frequency heating on nalidixic acid-adapted shiga toxin-producing and non-pathogenic Escherichia coli strains in buffer. Food and Bioprocess Technology, 9(9), 1535-1541.

https://doi.org/10.1007/s11947-016-1740-z

Rossi, F., Rizzotti, L., Felis, G. E., \& Torriani, S. (2014). Horizontal gene transfer among microorganisms in food: current knowledge and future perspectives. Food Microbiology, 42, 232-243. 
Rumbo, C., Fernández-Moreira, E., Merino, M., Poza, M., Mendez, J. A., Soares, N. C., Mosquera, A., Chaves, F., \& Bou, G. (2011). Horizontal transfer of the OXA-24 carbapenemase gene via outer membrane vesicles: a new mechanism of dissemination of carbapenem resistance genes in Acinetobacter baumannii. Antimicrobial Agents and Chemotherapy, 55(7), 3084-3090.

https://doi.org/10.1128/aac.00929-10

Russell, A. D. (2003). Lethal effects of heat on bacterial physiology and structure. Science Progress, 86(1-2), 115-137.

https://doi.org/10.3184/003685003783238699

Sarjit, A., Ravensdale, J. T., Coorey, R., Fegan, N., \& Dykes, G. A. (2021a). Survival of Salmonella on red meat in response to dry heat. Journal of Food Protection, 84(3), 372-380.

https://doi.org/10.4315/jfp-20-274

Sarjit, A., Ravensdale, J. T., Coorey, R., Fegan, N., \& Dykes, G. A. (2021b). Salmonella survival after exposure to heat in a model meat juice system. Food Microbiology, 94, 103628.

https://doi.org/10.1016/j.fm.2020.103628

Schjørring, S., \& Krogfelt, K. A. (2011). Assessment of bacterial antibiotic resistance transfer in the gut. International Journal of Microbiology, 2011, Article ID 312956. https://doi.org/10.1155/2011/312956

Shen, C., Geornaras, I., Belk, K. E., Smith, G. C., \& Sofos, J. N. (2011). Inactivation of Escherichia coli O157: H7 in moisture-enhanced nonintact beef by pan-broiling or 
roasting with various cooking appliances set at different temperatures. Journal of Food Science, 76(1), M64-M71.

https://doi.org/10.1111/j.1750-3841.2010.01882.x

Sommer, J., Trautner, C., Witte, A. K., Fister, S., Schoder, D., Rossmanith, P., \& Mester, P. J. (2019). Don't shut the stable door after the phage has bolted-The importance of bacteriophage inactivation in food environments. Viruses, 11(5), 468. https://doi.org/10.3390/v11050468

Sparo, M., Delpech, G., \& García Allende, N. (2018). Impact on public health of the spread of high-level resistance to gentamicin and vancomycin in enterococci. Frontiers in Microbiology, 9, 3073.

https://doi.org/10.3389/fmicb.2018.03073

Stopforth, J. D., Suhalim, R., Kottapalli, B., Hill, W. E., \& Samadpour, M. (2008). Thermal inactivation D-and z-values of multidrug-resistant and non-multidrugresistant Salmonella serotypes and survival in ground beef exposed to consumerstyle cooking. Journal of Food Protection, 71(3), 509-515.

https://doi.org/10.4315/0362-028x-71.3.509

Taher, E. M., Hemmatzadeh, F., Aly, S. A., Elesswy, H. A., \& Petrovski, K. R. (2020a). Survival of staphylococci and transmissibility of their antimicrobial resistance genes in milk after heat treatments. LWT, 109584.

https://doi.org/10.1016/j.lwt.2020.109584

Taher, E. M., Hemmatzadeh, F., Aly, S. A., Elesswy, H. A., \& Petrovski, K. R. (2020b). Molecular characterization of antimicrobial resistance genes on farms and in commercial milk with emphasis on the effect of currently practiced heat treatments on viable but nonculturable formation. Journal of Dairy Science, 103(11), 9936-9945. 
Toyofuku, M., Nomura, N., \& Eberl, L. (2019). Types and origins of bacterial membrane vesicles. Nature Reviews Microbiology, 17(1), 13-24.

https://doi.org/10.1038/s41579-018-0112-2

Uddin, M. J., Dawan, J., Jeon, G., Yu, T., He, X., \& Ahn, J. (2020). The role of bacterial membrane vesicles in the dissemination of antibiotic resistance and as promising carriers for therapeutic agent delivery. Microorganisms, 8(5), 670. https://doi.org/10.3390/microorganisms8050670

Verraes, C., Van Boxstael, S., Van Meervenne, E., Van Coillie, E., Butaye, P., Catry, B., Schaetzen, M. A., Huffel, X. V., Imberechts, H., Dierick, K., Daube, G., Saegerman, C., De Block, J., Dewulf, J., \& Daube, G. (2013). Antimicrobial resistance in the food chain: a review. International Journal of Environmental Research and Public Health, 10(7), 2643-2669.

https://doi.org/10.3390/ijerph10072643

Von Wintersdorff, C. J., Penders, J., Van Niekerk, J. M., Mills, N. D., Majumder, S., Van Alphen, L. B., Savelkoul, P. H. M., \& Wolffs, P. F. (2016). Dissemination of antimicrobial resistance in microbial ecosystems through horizontal gene transfer. Frontiers in Microbiology, 7, 173.

https://doi.org/10.3389/fmicb.2016.00173

Wagner, T., Joshi, B., Janice, J., Askarian, F., Škalko-Basnet, N., Hagestad, O. C., Mekhkif, A., Wai, S. N., Hegstad, K., \& Johannessen, M. (2018). Enterococcus faecium produces membrane vesicles containing virulence factors and antimicrobial resistance related proteins. Journal of Proteomics, 187, 28-38.

https://doi.org/10.1016/i.jprot.2018.05.017 
Walsh, C., Duffy, G., Sheridan, J. J., Fanning, S., Blair, I. S., \& McDowell, D. A. (2005). Thermal resistance of antibiotic-resistant and antibiotic-sensitive Salmonella spp. on chicken meat. Journal of Food Safety, 25(4), 288-302.

https://doi.org/10.1111/j.1745-4565.2005.00021.x

Walsh, D., Sheridan, J. J., Duffy, G., Blair, I. S., McDowell, D. A., \& Harrington, D. (2001). Thermal resistance of wild-type and antibiotic-resistant Listeria monocytogenes in meat and potato substrates. Journal of Applied Microbiology, 90(4), 555-560.

https://doi.org/10.1046/j.1365-2672.2001.01284.x

Wang, X., Lim, H. J., \& Son, A. (2014). Characterization of denaturation and renaturation of DNA for DNA hybridization. Environmental Health and Toxicology, 29, e2014007.

https://doi.org/10.5620/eht.2014.29.e2014007

Wesche, A. M., Gurtler, J. B., Marks, B. P., \& Ryser, E. T. (2009). Stress, sublethal injury, resuscitation, and virulence of bacterial foodborne pathogens. Journal of Food Protection, 72(5), 1121-1138.

https://doi.org/10.4315/0362-028x-72.5.1121

WHO (World Health Organisation) (2018a). Antimicrobial resistance. Available at: https://www.who.int/en/news-room/fact-sheets/detail/antimicrobial-resistance. (Last accessed: June 2020).

WHO (World Health Organisation) (2018b). Critically Important Antimicrobials for Human Medicine. $6^{\text {th }}$ Revision 2018. Available at: https://www.who.int/publications//item/9789241515528. (Last accessed: July 2021). 
Woegerbauer, M., Bellanger, X., \& Merlin, C. (2020). Cell-Free DNA: An underestimated source of antibiotic resistance gene dissemination at the interface between human activities and downstream environments in the context of wastewater reuse. Frontiers in Microbiology, 11, 671.

https://doi.org/10.3389/fmicb.2020.00671

Woode, B. K., Daliri, F., \& Daliri, E. B. M. (2020). Correlation between food processing-associated stress tolerance and antimicrobial resistance in food pathogens. Journal of Food Hygiene and Safety, 35(2), 103-108.

https://doi.org/10.13103/jhs.2020.35.2.103

Wright, G. D. (2007). The antibiotic resistome: the nexus of chemical and genetic diversity. Nature Reviews Microbiology, 5, 175-186.

Xu, A., Chuang, S., Scullen, O. J., Huang, L., Sheen, S., Sheen, L. Y., Johnson, J. R., \& Sommers, C. H. (2019). Thermal inactivation of extraintestinal pathogenic Escherichia coli suspended in ground chicken meat. Food Control, 104, 269-277. https://doi.org/10.1016/i.foodcont.2019.05.001

Yehia, H. M., Al-Masoud, A. H., Alarjani, K. M., \& Alamri, M. S. (2020). Prevalence of methicillin-resistant (mecA gene) and heat-resistant Staphylococcus aureus strains in pasteurized camel milk. Journal of Dairy Science, 103(7), 5947-5963. https://doi.org/10.3168/jds.2019-17631

Yu, T., Jiang, X., Liang, Y., Zhu, Y., Tian, J., Ying, H., Wang, X., \& Shi, L. (2017). Characterization and horizontal transfer of antimicrobial resistance genes and integrons in bacteria isolated from cooked meat products in China. Journal of Food Protection, 80, 2048-2055. 
Yu, T., Zhang, J., Jiang, X., Wu, J., Dai, Z., Wu, Z., Liang, Y., \& Wang, X. (2016). Characterization and horizontal transfer of class 1 integrons in Escherichia coli isolates from cooked meat products. Journal of Infection in Developing Countries, 10, 68-73.

https://doi.org/10.3855/jidc.6858

Zhang, Y., \& Wang, B. (2018). Comparison of the efficacy of commercial antimicrobial interventions for reducing antibiotic resistant and susceptible beefassociated Salmonella and Escherichia coli strains. Journal of Consumer Protection and Food Safety, 13(1), 3-23.

https://doi.org/10.1007/s00003-017-1141-x 